\title{
Translocation and Functional Analysis of Pseudomonas savastanoi pv. savastanoi NCPPB 3335 Type III Secretion System Effectors Reveals Two Novel Effector Families of the Pseudomonas syringae Complex
}

\author{
Isabel M. Matas, ${ }^{1}$ M. Pilar Castañeda-Ojeda, ${ }^{1}$ Isabel M. Aragón, ${ }^{1}$ María Antúnez-Lamas, ${ }^{2,3}$ \\ Jesús Murillo, ${ }^{4}$ Pablo Rodríguez-Palenzuela, ${ }^{2,3}$ Emilia López-Solanilla, ${ }^{2,3}$ and Cayo Ramos ${ }^{1}$ \\ ${ }^{1}$ Instituto de Hortofruticultura Subtropical y Mediterránea "La Mayora", Universidad de Málaga-Consejo Superior de \\ Investigaciones Científicas (IHSM-UMA-CSIC), Área de Genética, Facultad de Ciencias, Campus Teatinos s/n, E-29010 \\ Málaga, Spain; ${ }^{2}$ Centro de Biotecnología y Genómica de Plantas (CBGP), Universidad Politécnica de Madrid-Instituto \\ Nacional de Investigación y Tecnología Agraria y Alimentaria, Parque Científico y Tecnológico de la UPM, Campus de \\ Montegancedo, 28223 Pozuelo de Alarcón, Madrid; ${ }^{3}$ Departamento de Biotecnología. Escuela Técnica Superior de \\ Ingenieros Agrónomos, UPM. Avda, Complutense S/N, 28040, Madrid; ${ }^{4}$ Departamento de Producción Agraria, ETS \\ Ingenieros Agrónomos, Universidad Pública de Navarra, 31006 Pamplona, Spain
}

Submitted 26 July 2013. Accepted 28 November 2013.

Pseudomonas savastanoi pv. savastanoi NCPPB 3335 causes olive knot disease and is a model pathogen for exploring bacterial infection of woody hosts. The type III secretion system (T3SS) effector repertoire of this strain includes 31 effector candidates plus two novel candidates identified in this study which have not been reported to translocate into plant cells. In this work, we demonstrate the delivery of seven NCPPB 3335 effectors into Nicotiana tabacum leaves, including three proteins from two novel families of the $P$. syringae complex effector super-repertoire (HopBK and HopBL), one of which comprises two proteins (HopBL1 and HopBL2) that harbor a SUMO protease domain. When delivered by $\boldsymbol{P}$. fluorescens heterologously expressing a $P$. syringae T3SS, all seven effectors were found to suppress the production of defense-associated reactive oxygen species. Moreover, six of these effectors, including the truncated versions of HopAA1 and HopAZ1 encoded by NCPPB 3335, suppressed callose deposition. The expression of HopAZ1 and HopBL1 by functionally effectorless $P$. syringae pv. tomato DC3000D28E inhibited the hypersensitive response in tobacco and, additionally, expression of HopBL2 by this strain significantly increased its competitiveness in $N$. benthamiana. DNA sequences encoding HopBL1 and HopBL2 were uniquely detected in a collection of $31 P$. savastanoi pv. savastanoi strains and other $P$. syringae strains isolated from woody hosts, suggesting a relevant role of these two effectors in bacterial interactions with olive and other woody plants.

Current address for I. M. Matas: Instituto de Agrobiotecnología, CSICUPNA-Gobierno de Navarra, Universidad Pública de Navarra, Campus Arrosadía, 31192 Mutilva, Spain.

Corresponding author: C. Ramos; Telephone: +34-95213 1955; Fax: +3495213 2001; E-mail: crr@uma.es

* The $\boldsymbol{e}$-Xtra logo stands for "electronic extra" and indicates that six supplementary tables and one supplementary figure are published online.

(C) 2014 The American Phytopathological Society
Type III secretion system (T3SS) effectors (T3E) delivered by bacterial pathogens are key elements for establishing infection. In bacterial plant pathogens, these proteins primarily interfere with the plant immune system at two main defense layers: pathogen-associated molecular pattern (PAMP)-triggered immunity (PTI) and effector-triggered immunity (ETI) (Chisholm et al. 2006; Jones and Dangl 2006). Because there is an overlap between these two layers of immunity, T3E may target PTI, ETI, or both (Boller and Felix 2009; Katagiri and Tsuda 2010). Examples include the Pseudomonas syringae effector AvrPtoB, which has been demonstrated to suppress both PTI and ETI (de Torres et al. 2006; Lin et al. 2006). The production of reactive oxygen species (ROS) is one of the earliest cellular responses associated with plant immunity (Doke 1983). ROS can directly strengthen the host cell wall (Bradley et al. 1992; Huckelhoven 2007) and are important signals that mediate defense gene activation (Levine et al. 1994; Torres and Dangl 2005). Moreover, this oxidative burst is associated with the hypersensitive response (HR), a localized response at the site of pathogen attack characterized by the induction of programmed cell death (Mur et al. 2008) that limits pathogen spread.

The growing availability of bacterial genomes and the evolution of bioinformatics tools have revolutionized the discovery of novel plant pathogen effectors. Genome-wide searches for motifs shared by known T3E have recently revealed a repertoire of these proteins in plant bacterial pathogens, including $P$. syringae and related pathogens (Collmer et al. 2009; Lindeberg 2012; Lindeberg et al. 2008). The P. syringae complex, which encompasses up to 10 Pseudomonas spp. and 60 P. syringae pathovars (Young 2010), has become a model for a systems-level exploration of effector repertoires and their functions in biotrophic pathogenesis. T3E proteins of $P$. syringae and related plant pathogens are generically known as Hrp outer proteins (hops) (Lindeberg et al. 2005). Over 60 effector families, whose expression is transcriptionally activated by the alternative $\sigma$ factor HrpL (Xiao and Hutcheson 1994), are currently defined in the $P$. syringae pangenome. Currently, three $P$. syringae strains $-P$. syringae pv. tomato DC3000 (Alfano and Collmer 1996), P. syringae pv. phaseolicola 1448A (Jackson et 
al. 1999) and P. syringae pv. syringae B728a (Hirano and Upper 2000) - prevail as model systems for identifying and functionally analyzing protein effectors. Each strain provides a different perspective on the complex interactions of this pathogen with herbaceous plants. Comparisons of T3E gene repertoires within a phylogenetic context has elucidated the molecular basis of host specialization and host range evolution in fully or partially sequenced $P$. syringae pathovars (Baltrus et al. 2011, 2012; Lindeberg 2012; Lindeberg et al. 2012). However, a molecular mechanism governing $P$. syringae pathovar adaptation to woody hosts remains undefined.

P. savastanoi pv. savastanoi NCPPB 3335 causes olive knot disease and is a model bacterium to study the molecular basis of disease production and tumor formation in woody hosts (Ramos et al. 2012). As previously established for several $P$. syringae strains (Cunnac et al. 2009; Mansfield 2009), $P$. savastanoi pv. savastanoi NCPPB $3335 \mathrm{~T} 3 \mathrm{SS}$ is required for infection establishment and knot formation on olive plants (Matas et al. 2012; Pérez-Martínez et al. 2010). Additionally, bioinformatics analysis of the draft genome sequence of NCPPB 3335 identified 30 putative T3E in this pathogen, 19 of which were more than $65 \%$ similar to previously described effectors based on their amino acid identity (RodríguezPalenzuela et al. 2010). Furthermore, sequencing of the threeplasmid complement of this strain revealed that two of these T3E genes, hopAFl and hopAOl, are encoded in plasmids (Bardaji et al. 2011). A later revision of this genome sequence discarded three of the previously identified nonhomologous T3SS and identified four new candidate effectors in NCPPB 3335: AvrPto1, HopAT1, HopAZ1, and AvrRpm2 (Ramos et al. 2012) (Hop Database). Among these 31 T3E candidates, only two are homologs of $P$. syringae T3E with a previously demonstrated enzymatic function (i.e., HopAO1, a protein tyrosine phosphatase [Underwood et al. 2007], and HopAB1, an E3 ubiquitin ligase [Janjusevic et al. 2006]). Moreover, translocation of effector proteins into plant cells through the T3SS has not been reported to date for $P$. savastanoi pv. savastanoi or any other $P$. syringae pathovar of woody hosts.

In this work, we searched for additional $P$. savastanoi pv. savastanoi NCPPB 3335 T3E candidates on the basis of proteindomain similarity to known plant-pathogen effectors. A group of selected candidates was further analyzed in relation to their translocation into plant cells and their inhibition of plant defense responses. In this study, we demonstrated the translocation of seven Hop-Cya fusions through the $P$. savastanoi pv. savastanoi T3SS, including three novel T3E of the $P$. syringae complex, which belong to two new effector families; that is, HopBK (HopBK1) and HopBL (HopBL1 and HopBL2).

\section{RESULTS}

\section{Bioinformatics prediction of novel T3E in the $P$. savastanoi pv. savastanoi NCPPB 3335 genome.}

We started with the set of candidate effector genes identified previously in the $P$. savastanoi pv. savastanoi NCPPB 3335 genome (Rodríguez-Palenzuela et al. 2010) and later updated (Ramos et al. 2012). In addition, we searched specifically for NCPPB 3335 proteins with pfam domains (The Pfam Database) already found in known T3E (details below and in Supplementary Table S1). Two novel candidate T3E (AER-0000509 and

Table 1. Putative type III effectors identified in the Pseudomonas savastanoi pv. savastanoi NCPPB 3335 genome $^{\text {a }}$

\begin{tabular}{|c|c|c|c|c|c|c|}
\hline ID-ASAP & Locus tag & Pfam $^{\text {b }}$ & Name & Reference & Homolog ${ }^{c}$ & Reference \\
\hline AER-0005350 & PSA3335_1360 & PF11725 & avrE1 & Ramos et al. 2012 & + & Badel et al. 2006, Vinatzer et al. 2006 \\
\hline AER-0005727 & PSA3335_5082 & PF11592 & avrPto1 & Ramos et al. 2012 & + & Vinatzer et al. 2006 \\
\hline AER-0005728 & PSA3335_5091 & None & avrRpm2 & Ramos et al. 2012 & nd & ... \\
\hline AER-0002657 & PSA3335_5065 & None & HopA1 & Rodríguez-Palenzuela et al. 2010 & + & Chang et al. 2005 \\
\hline AER-0000274 & na & None & HopAA1 & Ramos et al. 2012 & - & Chang et al. 2005 \\
\hline AER-0004725 & PSA3335_2333 & PF09046 & HopAB 1 & Rodríguez-Palenzuela et al. 2010 & + & Chang et al. 2005, Vinatzer et al. 2006 \\
\hline AER-0000741 & PSA3335_4315 & PF15457 & HopAE1 & Rodríguez-Palenzuela et al. 2010 & + & Vinatzer et al. 2006 \\
\hline AER-0000968 & PSA3335_1469 & None & HopAF1 & Ramos et al. 2012 & + & Chang et al. 2005 \\
\hline AER-0003643 & PSA3335_1477 & None & HopAF1-2\# & Rodríguez-Palenzuela et al. 2010 & + & Chang et al. 2005 \\
\hline AER-0001776 & PSA3335_2927 & PF00150 & НорАН2 & Rodríguez-Palenzuela et al. 2010 & + & Zumaquero et al. 2010 \\
\hline AER-0000610 & PSA3335_0875 & PF14566 & HopAO1\# & Rodríguez-Palenzuela et al. 2010 & + & Chang et al. 2005 \\
\hline AER-0005024 & PSA3335_4684 & None & HopAS1 & Rodríguez-Palenzuela et al. 2010 & + & Vencato et al. 2006 \\
\hline AER-0005726 & PSA3335_5084 & None & HopAT1' & Ramos et al. 2012 & $+^{\wedge}$ & Chang et al. 2005 \\
\hline AER-0000625 & PSA3335_5031 & PF10791 & HopAU1 & Rodríguez-Palenzuela et al. 2010 & + & Vencato et al. 2006 \\
\hline AER-0001017 & PSA3335_1783 & None & HopAZ1 & Ramos et al. 2012 & nd & $\ldots$ \\
\hline AER-0000696 & PSA3335_2068 & PF13974 & HopBK1 & Rodríguez-Palenzuela et al. 2010 & nd & ... \\
\hline AER-0000509 & PSA3335_0157 & PF02902 & HopBL1 & This study & nd & $\ldots$ \\
\hline AER-0003844 & PSA3335_4544 & PF02902 & HopBL2 & This study & nd & ... \\
\hline AER-0004681 & PSA3335_4805 & None & HopD1 & Rodríguez-Palenzuela et al. 2010 & + & Chang et al. 2005 \\
\hline AER-0000629 & PSA3335_0852 & None & HopG1 & Rodríguez-Palenzuela et al. 2010 & + & Chang et al. 2005 \\
\hline AER-0000168 & PSA3335_4509 & PF00226 & HopI1 & Rodríguez-Palenzuela et al. 2010 & + & Chang et al. 2005; Vinatzer et al. 2006 \\
\hline AER-0005351 & PSA3335_1358 & None & HopM1' & Rodríguez-Palenzuela et al. 2010 & + & Badel et al. 2003; Vinatzer et al. 2006 \\
\hline AER-0004680 & PSA3335_4804 & PF01156 & HopQ1 & Rodríguez-Palenzuela et al. 2010 & + & Chang et al. 2005 \\
\hline AER-0004685 & PSA3335_4809 & None & HopR1 & Rodríguez-Palenzuela et al. 2010 & + & Chang et al. 2005; Schechter et al. 2006 \\
\hline AER-0003015 & PSA3335_2327 & PF13485 & HopV1 & Rodríguez-Palenzuela et al. 2010 & + & Schechter et al. 2004 \\
\hline AER-0003833 & PSA3335_5066 & None & HopW1' & Rodríguez-Palenzuela et al. 2010 & + & Chang et al. 2005; Zumaquero et al. 2010 \\
\hline AER-0000344 & PSA3335_5061 & None & HP0344 & Rodríguez-Palenzuela et al. 2010 & nd & $\ldots$ \\
\hline AER-0000393 & PSA3335_1416 & None & HP0393 & Rodríguez-Palenzuela et al. 2010 & nd & $\ldots$ \\
\hline AER-0001113 & PSA3335_0894 & PF07090 & HP1113 & Rodríguez-Palenzuela et al. 2010 & nd & ... \\
\hline AER-0001936 & PSA3335_3242 & None & HP1936 & Rodríguez-Palenzuela et al. 2010 & nd & $\ldots$ \\
\hline AER-0002597 & PSA3335_0106 & PF15184 & HP2597 & Rodríguez-Palenzuela et al. 2010 & nd & $\ldots$ \\
\hline AER-0002714 & PSA3335_2804 & PF01565 & HP2714 & Rodríguez-Palenzuela et al. 2010 & nd & $\ldots$ \\
\hline AER-0003934 & PSA3335_1247 & None & HP3934 & Rodríguez-Palenzuela et al. 2010 & nd & ... \\
\hline
\end{tabular}


not available, and ${ }^{\wedge}=$ translocation tested for HopAT1 of $P$. syringae pv. tomato DC3000 but not for HopAT1'.

$\mathrm{b}$ Accession number for the corresponding protein families at the pfam database.

c Homolog translocated in P. syringae. 
AER-0003844) were found, both containing the domain PF02902. This domain, which belongs to the Ulp1 protease family with SUMO protease activity, has been associated with several known effector proteins in pathogenic bacteria of the genus Xanthomonas, such as XopD (Kay and Bonas 2009). The final set of 33 candidate $P$. savastanoi pv. savastano NCPPB 3335 effectors is listed in Table 1, which includes these two novel putative T3E. Based on the translocation, functional, and phylogenetic analysis of these proteins shown below, and taking into account the guidelines for a unified nomenclature of T3E in the plant pathogen $P$. syringae proposed by Lindenberg and associates (2005), hereafter these T3E are called HopBL1 (AER-0000509) and HopBL2 (AER-0003844) (Table 1; Supplementary Table S2).
Translocation assay of T3E candidates revealed novel effectors in $\boldsymbol{P}$. savastanoi.

Of the 33 candidate $P$. savastanoi pv. savastano NCPPB 3335 T3E, 12 were selected for further analysis (Table 1). These candidates included the three proteins with a $P$. syringae homo$\log$ for which plant-cell translocation has not been demonstrated to date (AvrRpm2, HopAA1, and HopAZ1). Additionally, we selected seven of the 10 hypothetical T3E identified in the genome of $P$. savastanoi pv. savastanoi NCPPB 3335 that are not present in $P$. syringae pv. phaseolicola 1448 A, its closest relative that infects herbaceous plants for which there is a closed genome. The selection also included AER-0003934, which harbors a homolog in the genome of 1448A, and HopA1 (AER-0002657). With the exception of the hopAl gene,

Table 2. Occurrence of consensus Hrp-box sequences upstream of type III secretion system effector genes from Pseudomonas savastanoi pv. savastanoi NCPPB 3335

\begin{tabular}{lcl}
\hline Gene name & Hrp-box position ${ }^{\text {a }}$ & \multicolumn{1}{c}{ Hrp-box sequence } \\
\hline Consensus & $\ldots$ & BGGAACYHNNNNNNNNNNNNNNNCCACNHAG \\
avrPto1 & -69 to -39 & TGGAACCGACCTGCCCCCGATGACCACTCAG \\
avrRpm 2 & -474 to -444 & TGGAACCAAATATGTAGTTATGGTCACTCAC \\
hopAA1 & -193 to -163 & TGGAACCGTCAACGGATCCGGGACCACACAG \\
hopAZ1 & -124 to -94 & TGGAACCTCTCCTCAATGAGTTGCCACTCAC \\
hopBK1 & -218 to -197 & AGGTGCGCCGGGGTTATGACGAGGCCACGGTG \\
hopBL1 & -244 to -214 & TGGAACCTAATCGCTGGAGAGGCCTACTAAT \\
hopBL2 & -412 to -383 & AGGAATTTAAGCTCGATAGTTGCCACAGTC \\
HP0344 & -184 to -155 & GGCAAGGCGCCTGCACCTAGAGCCACAACG \\
HP0393 & -56 to -26 & AGGAACCCGGCCCACGCAAGTGGACACCCGG \\
HP1113 & -84 to -55 & TGAAACCCTTTTGATCGACAACCCACGCCG \\
HP2714 & -82 to -53 & AGGACCCGGTAGTTTCGCAATCCGCGACC \\
HP3934 & $\ldots 3$ to -451 & TGGAACCTGTTCAATGTGCTGTCGGCACCCGC \\
hopA1 & $\ldots$ & na
\end{tabular}

${ }^{a}$ Coordinates are with respect to the annotated start codon of the coding sequence.

${ }^{\mathrm{b}}$ Consensus Hrp box sequence (Fouts et al. 2002). Conserved sequences are highlighted in bold; na $=$ not available in the draft genome sequence of $P$. savastanoi pv. savastanoi NCPPB 3335.

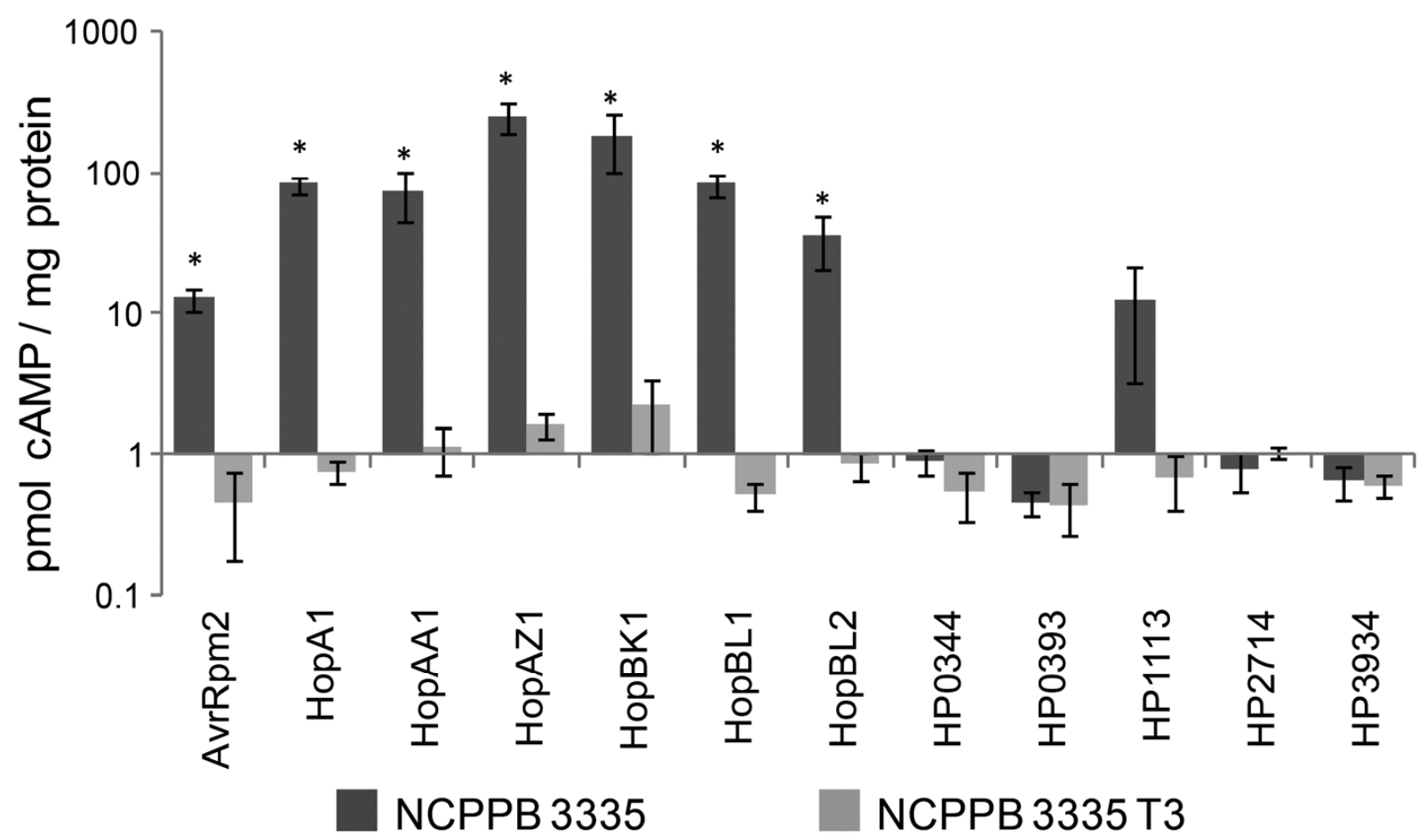

Fig. 1. Translocation assay of candidate Pseudomonas savastanoi pv. savastanoi NCPPB 3335 type III secretion system (T3SS) effectors (T3E) in Nicotiana tabacum var. Newdel plants by the NCPPB 3335 T3SS. Calmodulin- and Cya-dependent production of cAMP was used to measure the translocation of T3ECya fusions into plant cells. $N$. tabacum plants were inoculated with $P$. savastanoi pv. savastanoi NCPPB 3335 or NCPPB 3335 -T3 (T3SS mutant) expressing the indicated Hop-Cya fusions from pCPP3234 derivatives. T3E are denoted by their corresponding names. Values represent the mean and standard error for samples obtained in triplicate; similar results were obtained in multiple experiments. Asterisks indicate significant differences $(P=0.05)$ between the cAMP levels obtained for the NCPPB 3335 and NCPPB 3335-T3 strains. 
whose upstream region is not available in the draft genome sequence of $P$. savastanoi pv. savastanoi NCPPB 3335 (Rodríguez-Palenzuela et al. 2010), an identifiable Hrp box (Fouts et al. 2002) was found in the 500 nucleotides upstream of the start codon of the other $11 \mathrm{~T} 3 \mathrm{E}$ candidates (Table 2 ).

To determine whether the selected candidate effectors were T3SS substrates that could translocate into plant cells, we constructed pCPP3234 derivatives (Supplementary Table S3) expressing fusions of Bordetella pertussis adenylate cyclase (Cya) to the $\mathrm{C}$ terminus of full-length T3E. This system, which is based in cyclic AMP (cAMP) production exclusively in the presence of eukaryotic calmodulin, has been widely used for analyzing the translocation of $P$. syringae T3E (Casper-Lindley et al. 2002; Schechter et al. 2004; Sory and Cornelis 1994).

Nicotiana tabacum leaves were infiltrated with either $P$. savastanoi pv. savastanoi NCPPB 3335 or the strain NCPPB 3335-T3, a T3SS mutant derived from wild-type NCPPB 3335 (Pérez-Martínez et al. 2010), expressing each of the 12 constructed Cya fusions. Significant differences in cAMP production between the wild-type strain and the T3SS mutant strain were observed in seven of the 12 candidate T3E testedAvrRpm2, HopA1, HopAA1, HopAZ1, HopBK1 (the first described member of a novel effector family of the $P$. syringae complex), HopBL1, and HopBL2 (Fig. 1)-indicative of their translocation through the $P$. savastanoi pv. savastanoi T3SS. Notably, HopA1 was translocated by $P$. savastanoi pv. savastanoi in tobacco (Fig. 1), as expected because its homolog in $P$. syringae pv. tomato DC 3000 has been shown to be translocated into Arabidopsis leaves (Chang et al. 2005).

HrpL-dependent expression of novel $P$. savastanoi T3E.

To unveil the HrpL-dependent expression of the three hypothetical proteins identified here as novel T3E of the $P$. syringae complex (HopBK1, HopBL1, and HopBL2), a $\Delta$ hrpL P. savastanoi pv. savastanoi NCPPB 3335 mutant was constructed. As previously described for the $P$. savastanoi pv. savastano NCPPB 3335-T3 (Pérez-Martínez et al. 2010), the NCPPB $3335 \Delta h r p L$ mutant was unable to elicit an HR in N. tabacum plants (Fig. 2A) or form knots in lignified olive plants (Fig. 2B). The expression of the hopBK1, hopBL1, and hopBL2 genes was analyzed using quantitative reverse-transcription polymerase chain reaction (qRT-PCR) with both the wild type and the NCPPB $3335 \Delta h r p L$ mutant. In addition, the expression of the avRPtol gene and the iaaM gene (encoding tryptophan monooxygenase, involved in the biosynthesis of indoleacetic acid) was also tested as positive and negative controls, respectively. Under noninducing conditions (cells grown in King's B [KB] medium), the expression of the hopBK1, hopBL1, and hopBL2 genes was comparable in the $\Delta h r p L$ mutant and the wild-type strain (data not shown). However, $6 \mathrm{~h}$ after the transfer of bacterial cells to Hrp-inducing medium, the expression of all three genes and the expression of the avrPtol gene decreased (0.002- to 0.4-fold) in the $\Delta h r p L$ mutant compared with the wild type, demonstrating an expression dependency on HrpL. As expected for the negative control, no reduction in the expression of the iaaM gene was observed under the same conditions (Fig. 2C).

Distribution of HopBK1, HopBL1, and HopBL2 T3E among $P$. savastanoi pv. savastanoi and related strains.

To study the conservation of the three new P. savastanoi pv. savastanoi NCPPB 3335 effectors among strains from the $P$. syringae complex, their protein sequences were used as queries to perform BLASTp searches against the nonredundant protein sequence database. The results revealed that HopBL1 and HopBL2 are similar to XopD of Xanthomonas spp. and infrequent within the $P$. syringae complex. Conversely, HopBK1 is present in $P$. syringae pathovars tomato, actinidae, aceris, oryzae, syringae, and lachrymans (Fig. 3A and B).

The hopBK1, hopBL1, and hopBL2 P. savastanoi pv. savastanoi NCPPB 3335 T3E genes were used as probes in dot-blot hybridizations to ascertain their distribution among a collection of 31 P. savastanoi pv. savastanoi strains isolated in different countries and among a selection of $P$. syringae strains isolated from either woody or herbaceous hosts. The strains used in this assay are presented in Supplementary Table S4. These three effector genes were present in most of the $P$. savastanoi pv. savastanoi strains, two strains of $P$. savastanoi pv. nerii $(2$ and 519), and in strains $P$. syringae pv. eriobotryae CFBP 2343, pv. morsprunorum CFBP 2116, and pv. myricae CFBP 2897 (Fig. 3C). The hopBKI gene was not detected in six $P$. savastanoi pv. savastanoi strains (CFBP 71, CFBP 1670, CFBP 1746, IMC-1, IVIA 1624-1b, and NCPPB 1479), P. syringae pv. dendropanacis CFBP 3226, and pv. mori CFBP 1642. Furthermore, hopBL1 and hopBL2 were absent in P. syringae pv. glycinea
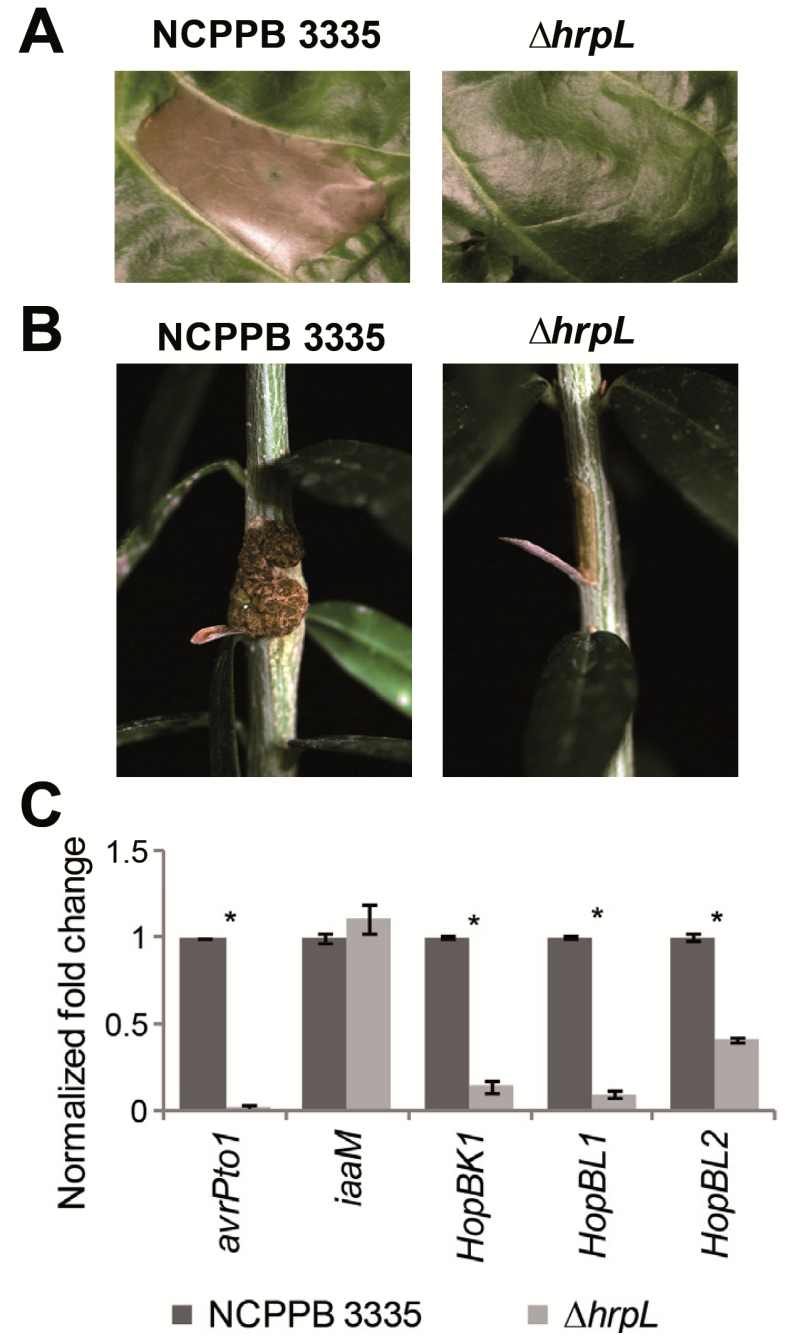

Fig. 2. HrpL-dependent expression of the Pseudomonas savastanoi pv. savastanoi NCPPB 3335 novel type III secretion system effectors (T3E). A, Hypersensitive response of Nicotiana tabacum var. Newdel leaves $24 \mathrm{~h}$ after infection with $P$. savastanoi pv. savastanoi NCPPB 3335 or NCPPB $3335 \Delta h r p L$. B, Symptoms induced in lignified olive plants 90 days after inoculation with NCPPB 3335 or NCPPB $3335 \Delta$ hrpL. C, Quantitative reverse-transcription polymerase chain reaction with the indicated $P$. savastanoi pv. savastanoi NCPPB 3335 T3E genes in NCPPB $3335 \Delta h r p L$ versus NCPPB 3335 at $6 \mathrm{~h}$ after transfer to Hrp-inducing medium. The fold change was calculated after normalization using the gyrA gene as an internal control. Results represent the means from three independent experiments. Error bars represent the standard deviation. 
PG4180, pv. lachrymans CFBP 1644, pv. sesami CFBP 1671, and pv. tomato PT23 (Fig. 3C). The widespread distribution of these three effectors among strains of $P$. savastanoi pv. savastanoi suggests that they might be important for the interaction with olive. However, their patchy distribution among pathovars infecting woody hosts indicate that they are not universally essential for the infection of woody plants and that their effect might be dependent on the particular pathosystem.

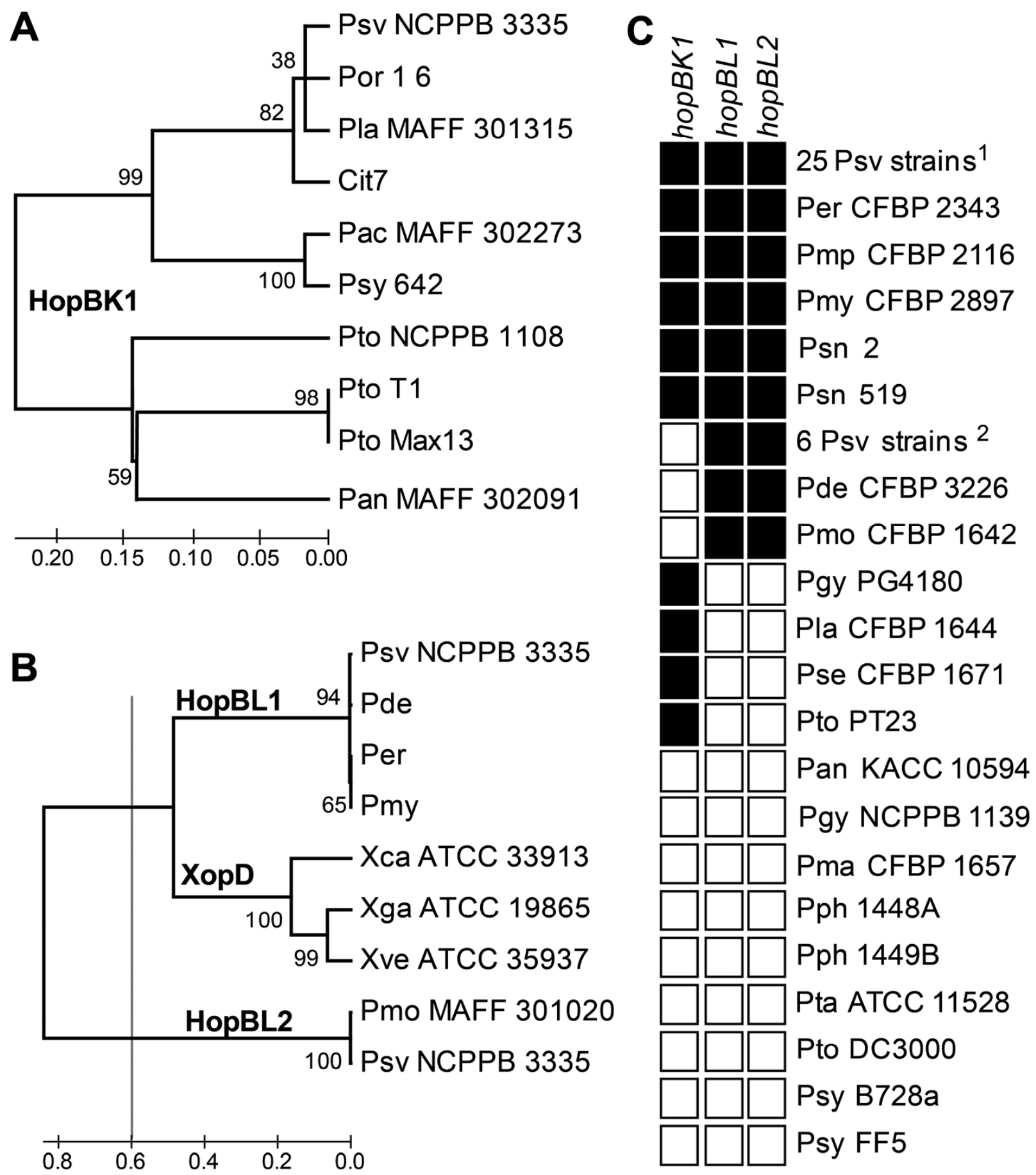

Fig. 3. Distribution and phylogeny of HopBK1, HopBL1 and HopBL2 among pathovars of the Pseudomonas syringae complex. Unrooted neighbor-joining tree of A, HopBK1 and $\mathbf{B}$, HopBL1 and HopBL2 proteins from strains of the P. syringae complex. HopBK1 is widely distributed in P. syringae pv. actinidiae, with at least two alleles showing $94 \%$ amino acid identity, although only a single strain is shown for clarity. Similar or identical topologies were obtained by maximum likelihood. Bootstrap percentage values (10,000 repetitions) are shown on the branches and evolutionary distances are given in units of amino acid substitutions per site. C, Distribution of the novel P. savastanoi pv. savastanoi NCPPB 3335 type III secretion system effector genes hopBK1, hopBL1, and hopBL2 among a collection of strains from the P. syringae complex isolated from woody and herbaceous plant hosts. A colony blot analysis was performed using the indicated gene probes. Strains are indicated by their pathovar abbreviation. Black and white squares represent the presence or absence, respectively, of strong hybridization signals with the indicated effectors for each strain analyzed. Superscript 1 indicates 25 strains of $P$. savastanoi pv. savastanoi: B15.00, C1.01, C2.01, C3.01, CFBP 1020, CFBP 2074, DAPP-PG722, IMC-2, ITM 317, IVIA 1628-3, IVIA 1629-1a, IVIA 1637-a, IVIA 1637B3, IVIA 1649-1, IVIA 1651-C15, IVIA 1657-A2, IVIA 1657-B8, IVIA 2733-1a, IVIA 2743-3, NCPPB 64, NCPPB 1342, NCPPB 1344, NCPPB 1506, NCPPB 3335, and PVFi-1; and superscript 2 indicates six strains of $P$. savastanoi pv. savastanoi: CFBP 71, CFBP 1670, CFBP 1746, IMC-1, IVIA 1624-1b, and NCPPB 1479 . 


\section{P. savastanoi pv. savastanoi NCPPB 3335 encodes truncated versions of HopAA1 and HopAZ1.}

The occurrence of premature stop codons and transposon disruptions is common in $\mathrm{T} 3 \mathrm{E}$ across the $P$. syringae phylogeny. Although these variants are generally considered to be functionless pseudogenes, the functional significance of these truncated alleles remains unresolved (Baltrus et al. 2011). The $P$. syringae hopAAl and hopAZl families contain alleles of vastly different lengths. The truncated version of hopAAl encoded by $P$. savastanoi pv. savastanoi NCPPB 3335 (189 amino acids) harbors a single nucleotide insertion within codon 188 relative to the full-length hopAAl-1 allele of $P$. syringae pv. tomato DC3000 (486 amino acids). Truncations of the hopAAl gene have also been identified in $P$. syringae pvs. phaseolicola and actinidiae (Fig. 4). On the other hand, $P$. savastanoi pv. savastanoi NCPPB 3335 also contains a truncated version of hopAZ1, encoding a polypeptide of 122 amino acids lacking the C-terminal domain of the HopAZ1 versions encoded by other $P$. syringae pathovars (Fig. 4). The truncated versions of the hopAAl and hopAZl genes encoded by $P$. savastanoi pv. savastanoi NCPPB 3335 were included in the plant bioassays described below, in order to determine their functionality during plant infection.

\section{Heterologous expression of $P$. savastanoi T3E in the nonpathogen $P$. fluorescens 55 expressing a cloned $P$. syringae Hrp system.}

$\mathrm{T} 3 \mathrm{E}$ activities interfere with the innate immunity response of the plant at different levels. ROS production and callose deposition upon pathogen recognition are early plant defense responses. To test the ability of the seven $P$. savastanoi pv. savastanoi T3E identified here-AvrRpm2, HopA1, HopAA1, HopAZ1, HopBK1, HopBL1, and HopBL2-to attenuate these responses, we expressed their corresponding genes (pCPP5040 derivatives) in P. fluorescens 55 (pLN18), which heterologously expresses a $P$. syringae T3SS, thus enabling the delivery of effector proteins into plant cells at levels characteristic of a natural infection (Jamir et al. 2004; Lopez-Solanilla et al. 2004; Oh et al. 2010; Rodríguez-Herva et al. 2012). For this purpose, $N$. tabacum leaves were used. PAMPs displayed by $P$. fluorescens 55 generate a PTI response in inoculated plants, which is increased by the pLN18-encoded T3SS, as indicated by a higher ROS level than that induced by $P$. fluorescens 55 without a T3SS (Oh et al. 2010). The ROS levels, determined by 3,3'-diaminobenzidine (DAB) staining, were significantly reduced by the expression of each of the seven T3E compared with the control strain $P$. fluorescens 55 (pLN18) harboring an empty vector (Tukey test; $P \leq 0.01$ ) (Fig. 5A and B). Moreover, with the exception of HopA1, all the other T3E significantly reduced the levels of callose deposition compared with the control strain (Tukey test; $P \leq 0.01$ ) (Fig. 5C and D). These results suggest that these T3E interfere with the early responses associated with plant immunity.

\section{Heterologous expression of $P$. savastanoi T3E} in the functionally effectorless polymutant $P$. syringae pv. tomato $\mathrm{DC} 3000 \mathrm{D} 28 \mathrm{E}$.

To further analyze the individual roles of the $P$. savastano $i$ pv. savastanoi T3E when confronting the plant immune system, we constructed derivatives of the $P$. syringae pv. tomato DC3000D28E strain expressing each of the seven effectors from the pCPP5040 plasmid. DC3000D28E is a polymutant of the model pathogen $P$. syringae pv. tomato DC3000 that harbors deletions in all 28 well-expressed effector genes. Thus, DC3000D28E is considered to be functionally effectorless but otherwise wild type in planta. Although the wild-type strain DC3000 induces an ETI-like rapid plant cell death in N. ben- thamiana and N. tabacum, DC3000D28E has a reduced ability to induce this response and seems to elicit plant defenses that are T3SS-dependent and additional to basal PTI (Cunnac et al. 2011). This elicitation is explained by the fact that DC3000D28E has the wild-type complement of T3SS helper proteins (except HrpW1), and several of these proteins can elicit plant defenses and induce an HR response (Cunnac et al. 2011; Kvitko et al. 2007). Therefore, this strain is an excellent tool to investigate the role of heterologous effectors in amenable systems, such as $N$. benthamiana and $N$. tabacum. DC3000D28E derivatives expressing the selected T3E were compared with DC3000D28E regarding their ability to elicit cell death in $N$. tabacum at two different inoculum levels, which were chosen to exceed the threshold typically needed to elicit cell death associated with ETI. Neither the polymutant strain DC3000D28E nor the derivatives expressing $P$. savastanoi pv. savastanoi T3E incited the HR response typical of the wild-type strain DC3000 at a bacterial dose of $2 \times 10^{7}$ $\mathrm{CFU} / \mathrm{ml}$. However, with $10 \times$ more bacteria $\left(2 \times 10^{8} \mathrm{CFU} / \mathrm{ml}\right)$, the polymutant strain stimulated an ETI-like response after 48 $\mathrm{h}$ of inoculation, which was partially or completely inhibited by the expression of the $P$. savastanoi pv. savastanoi proteins HopAZ1 and HopBL1, respectively (Fig. 6A and B). These results suggest that these two effectors participate in the inhibition of the plant defense response associated with the onset of programmed cell death.

The DC3000D28E strain has been shown to grow better in planta when coinoculated with a strain that is able to suppress plant immunity, such as DC3000 4 hopQ1-1 (Cunnac et al. 2011). Therefore, this strain is considered an excellent tool for testing the ability of individual T3E to restore bacterial growth or to induce specific plant responses. To investigate the effect of the seven $P$. savastanoi pv. savastanoi T3E on the ability of DC3000D28E to colonize $N$. benthamiana, competition assays between the polymutant strain (DC3000D28E) and each derivative expressing the selected T3E were conducted. $N$. bentham-
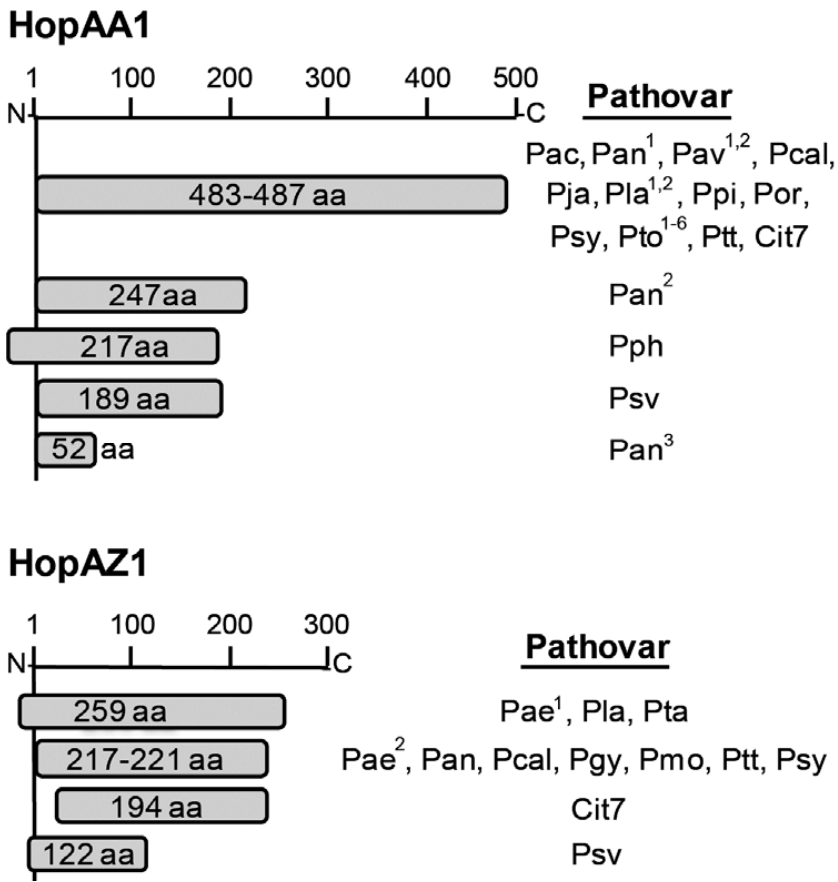

Fig. 4. Schematic map of HopAA1 and HopAZ1 alleles with variable protein length from the Pseudomonas syringae complex. Strains are indicated by their pathovar abbreviation. Superscript numbers indicate different strains or ortholog genes; aa = amino acids residues encoded by the corresponding genes. 
iana leaves were infiltrated with a mixed inoculum (1:1) of DC3000D28E and each of the derivatives and, after 6 days, bacteria were recovered and viable cells were determined. The results presented in Figure 6C are expressed as the competition indices (CI) of the derivatives expressing each of the $P$. savastanoi pv. savastanoi T3E relative to the DC3000D28E strain. Interestingly, the expression of $P$. savastanoi pv. savastanoi HopBL2 in DC3000D28E significantly increased the competitiveness of the strain, which was reflected in a CI value (HopBL2/DC3000D28E) of 21.1. Expression of HopAA1 also increased the competitiveness of the strain, although at a lower level $(\mathrm{CI}=2.6)$ than HopBL2. These results suggest that these effectors inhibit plant defense responses.

\section{DISCUSSION}

The recent availability of complete and draft genome sequences for several $P$. syringae and $P$. savastanoi pathovars and the relevant advances in the development of bioinformatics tools led to a comprehensive catalog of candidate effector repertoire for 19 different strains (Baltrus et al. 2011). Given that only nine new effector families were identified after the latest comparative genome-sequence analysis, the $P$. syringae complex effector super-repertoire may be nearly complete with 57 effector families (Baltrus et al. 2011; Lindeberg et al. 2012). However, novel candidate effectors identified using these strategies should be functionally characterized in the context of a unified model for a two-layered immune system in plants (Block and Alfano 2011; Lindeberg et al. 2012). To that end, in this study, we demonstrated that the Hrp T3SS mediated the delivery into plant cells of seven $P$. savastanoi pv. savastanoi NCPPB 3335 effectors, including HopA1; three T3E for which translocation into plant cells has not been demonstrated for any other P. syringae strain (AvrRpm2, HopAA1, and HopAZ1); and three novel T3E (HopBK1, HopBL1, and HopBL2) from two new effector families of the $P$. syringae complex (HopBK and HopBL) (Fig. 1). Moreover, we demonstrated that the expression of these three genes encoding novel T3E was transcriptionally dependent on HrpL.

Translocation assays based on Cya reporters were designed for use in herbaceous plants and require injection of bacterial suspensions expressing T3E-Cya fusions into fully expanded
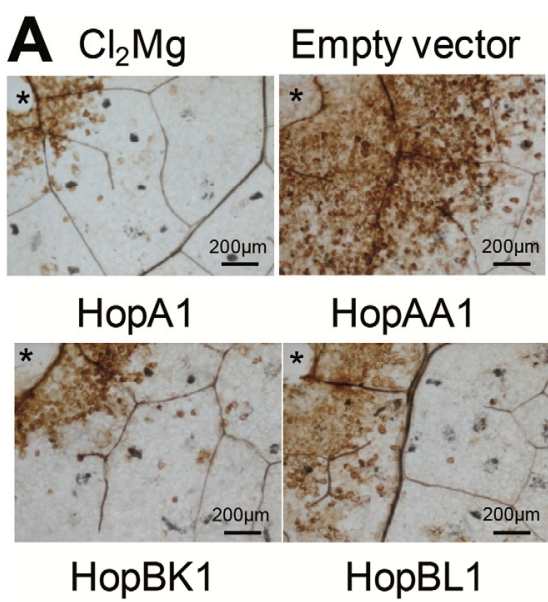

HopAA1
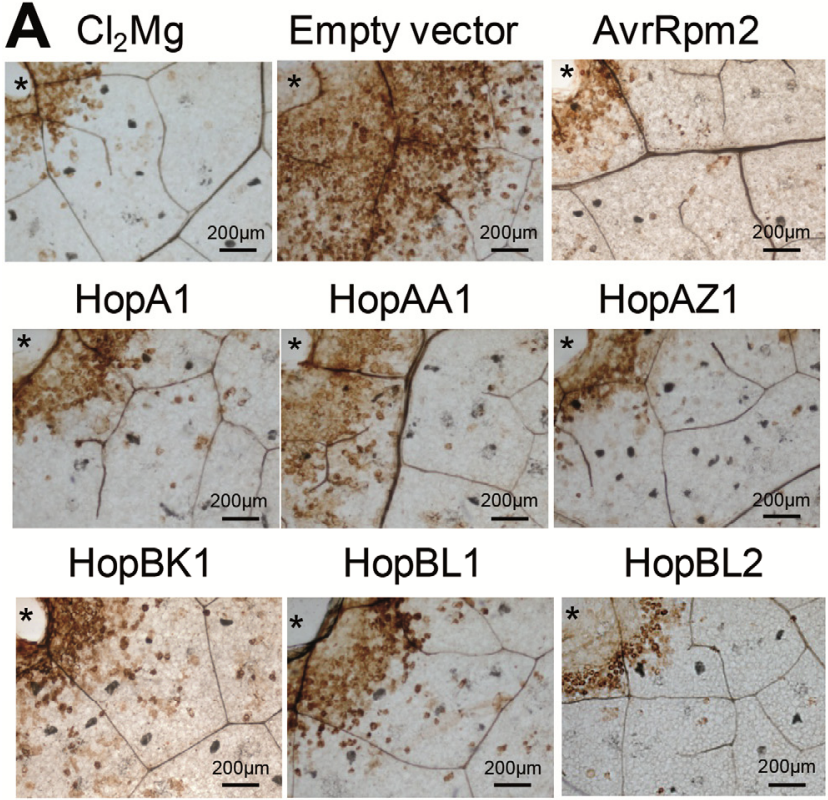

HopBL2

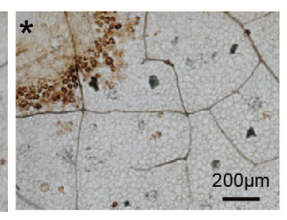



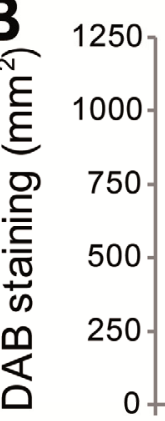
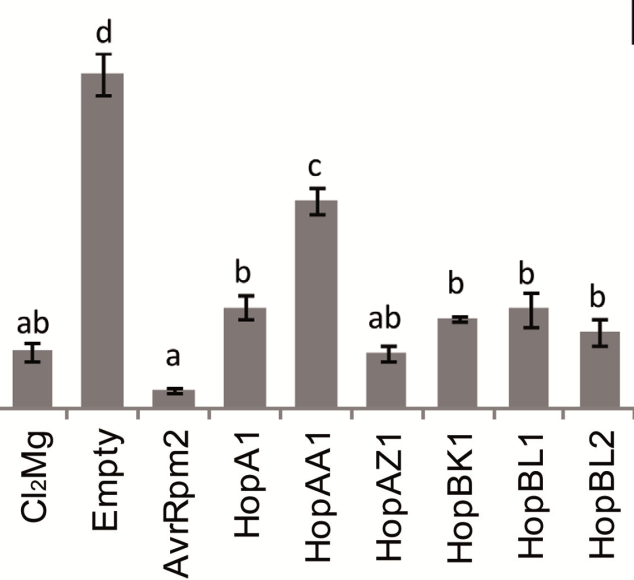
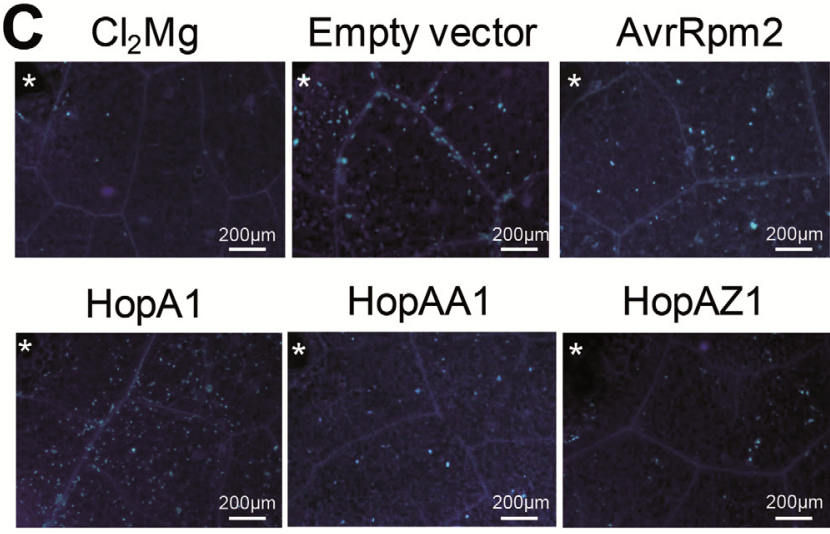

HopAA1

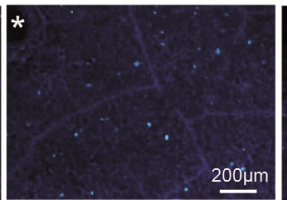

HopBK1

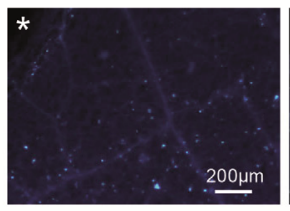

HopBL1
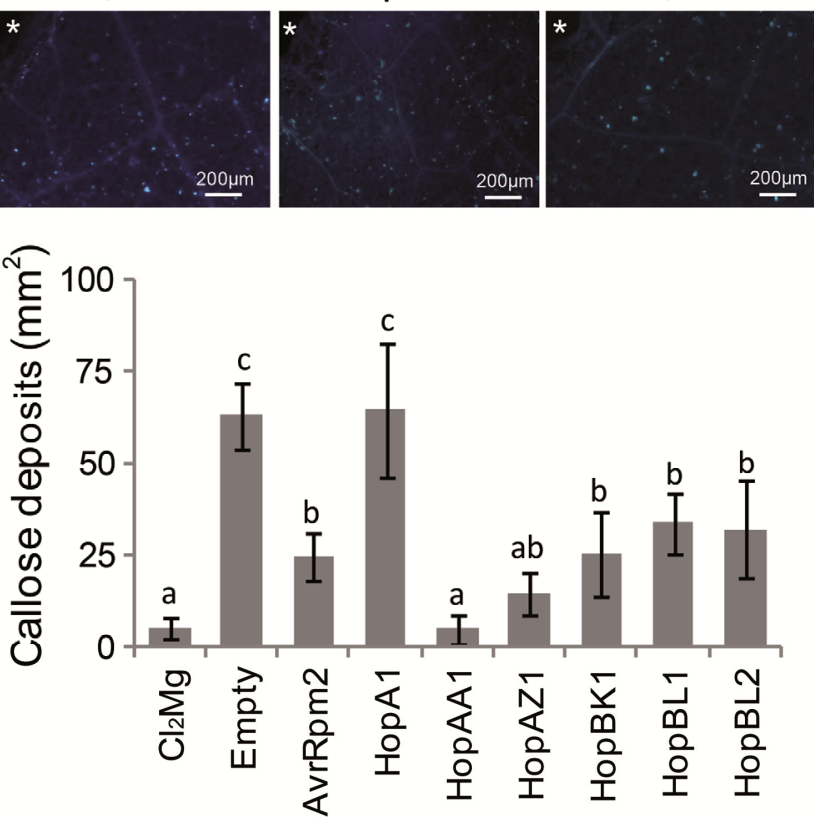

Fig. 5. 3,3'-Diaminobenzidine (DAB) staining and callose deposition in Nicotiana tabacum var. Xanthi leaves. Plants were challenged with Pseudomonas fluorescens 55 (pLN18) harboring the pCPP5040 empty vector or the vectors expressing the indicated P. savastanoi pv. savastanoi NCPPB 3335 type III secretion system effectors. A, The DAB signal was quantified $4 \mathrm{~h}$ after infection and $\mathbf{B}$, represented in a histogram. $\mathbf{C}$, The callose deposition was assessed using aniline blue staining, quantified $12 \mathrm{~h}$ after infection, and D, represented in a histogram. Asterisks in A and C indicate inoculation zones. For histograms, data are means \pm standard error of the mean for at least five replicas; bars topped with the same letter represent values that are not significantly different using one-way analysis of variance followed by post-hoc comparisons using the Tukey test. 
upper leaves. However, adapting this assay to study the interaction of bacterial effectors with a woody plant such as olive has been limited by two main restrictions, both due to secondary wall thickenings of the host. First, inoculating the olive plant stem with bacteria requires artificially wounding the plant material, a process that induces complex plant defense mechanisms (Conrath 2011); and, second, visualizing the damaged stem tissue after bacterial inoculation is complex. For these reasons, translocation assays of T3E through the $P$. savastanoi pv. savastanoi T3SS were performed in N. tabacum, a nonhost plant of this pathogen (Pérez-Martínez et al. 2010). Cya has been used as a reporter to study T3SS-mediated translocation of effector proteins by animal- and plant-pathogenic bacteria (Schechter et al. 2004). This system has been optimized in host and nonhost plants with the well-studied effector protein AvrPto from P. syringae pv. tomato. The translocation of several DC3000 candidate T3E has been assessed using this Cya reporter, which induces cAMP accumulation in tomato or $N$. benthamiana after effectors are delivered by the $P$. fluorescens 55, which expresses a $P$. syringae Hrp system (Schechter et al. 2004). Our results demonstrated that several P. savastanoi pv. savastanoi NCPPB 3335 effector proteins were translocated. However, we cannot exclude that the negative results obtained for some of the other candidate proteins tested were due to the induction of an HR response in $N$. tabacum, which impedes cAMP accumulation.

The $P$. syringae pangenome includes only four effector families that are considered core members of the effector superrepertoire: AvrE, HopI, HopM1, and HopAA (Baltrus et al. 2011; Lindeberg et al. 2012). Candidate effectors from all four families were identified in the genome of $P$. savastanoi $\mathrm{pv}$. savastanoi NCPPB 3335 (Table 1). Our in silico survey also demonstrated that the three novel T3E identified here (HopBK1, HopBL1, and HopBL2) are present in only a few $P$. syringae strains (Fig. 3A and B). In contrast, dot-blot hybridization analysis revealed that these three T3E were present in most $P$. savastanoi pv. savastanoi strains (Fig. 3C). Interestingly, hopBL1 and hopBL2 were detected in all $P$. savastanoi pv. savastanoi strains analyzed and in other $P$. syringae strains isolated from woody hosts, suggesting a relevant role for these effectors in the interaction of $P$. syringae and $P$. savastanoi with certain woody plants. However, this association did not occur with hopBK1, because it was not present in all $P$. savastanoi strains analyzed and was also detected in diverse $P$. syringae pathovars associated with herbaceous plants.

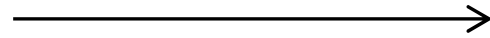

Fig. 6. Delivery of Pseudomonas savastanoi pv. savastanoi type III secretion system effectors (T3E) by functionally effectorless $P$. syringae pv. tomato DC3000D28E in Nicotiana leaves. A, Cell death response in Nicotiana tabacum var. Newdel leaves $48 \mathrm{~h}$ after inoculation with $P$. syringae pv. tomato strains DC3000 (wild type) or DC3000D28E cells suspended in $\mathrm{MgCl}_{2}$ and adjusted to the indicated densities (in CFU/ml). B, Cell death response in $N$. tabacum var. Newdel leaves $48 \mathrm{~h}$ after inoculation with $P$. syringae pv. tomato DC3000D28E cells suspended in $\mathrm{MgCl}_{2}$ carrying pCPP5040 (empty vector) derivatives expressing the indicated $P$. savastanoi pv. savastanoi NCPPB $3335 \mathrm{~T} 3 \mathrm{E}$ adjusted to $2 \times 10^{8} \mathrm{CFU} / \mathrm{ml}$. Cell death response: + = positive, $-=$ null, and $\pm=$ partial. Each experiment was repeated at least three times with similar results. C, Competition assays in $N$. benthamiana leaves between $P$. syringae pv. tomato DC3000D28E and each of its transformants carrying pCPP5040 derivatives expressing the indicated $P$. savastanoi pv. savastanoi T3E. Competition indices (CI) were normalized with respect to the CI obtained for DC3000D28E versus DC3000D28E expressing the empty vector (pCPP5040). Values are the mean \pm standard error of the mean of three replicates demonstrating typical results from three independent experiments; bars topped with the same letter represent values that are not significantly different using one-way analysis of variance followed by post-hoc comparisons using the Tukey test.
The vast majority of the $P$. syringae pv. tomato DC3000 T3E have been demonstrated to suppress ETI and many can also suppress PTI, suggesting that numerous T3E exert multiple activities or, alternatively, that common T3E targets are utilized in pathways needed for ETI, PTI, or both (Guo et al. 2009). Our results indicate that the seven $P$. savastanoi pv. savastanoi $\mathrm{NCPPB} 3335 \mathrm{~T} 3 \mathrm{E}$ shown to translocate in this study, including the truncated versions of HopAA1 and HopAZ1, interfered with early responses associated with plant defense. In addition, we demonstrated that HopAZ1 and HopBL1 also inhibited the ETI-like response incited by DC3000D28E in tobacco.

Although all the tested effectors significantly reduced ROS production, expression of HopA1 in P. fluorescens 55 did not significantly reduce callose deposition under the conditions

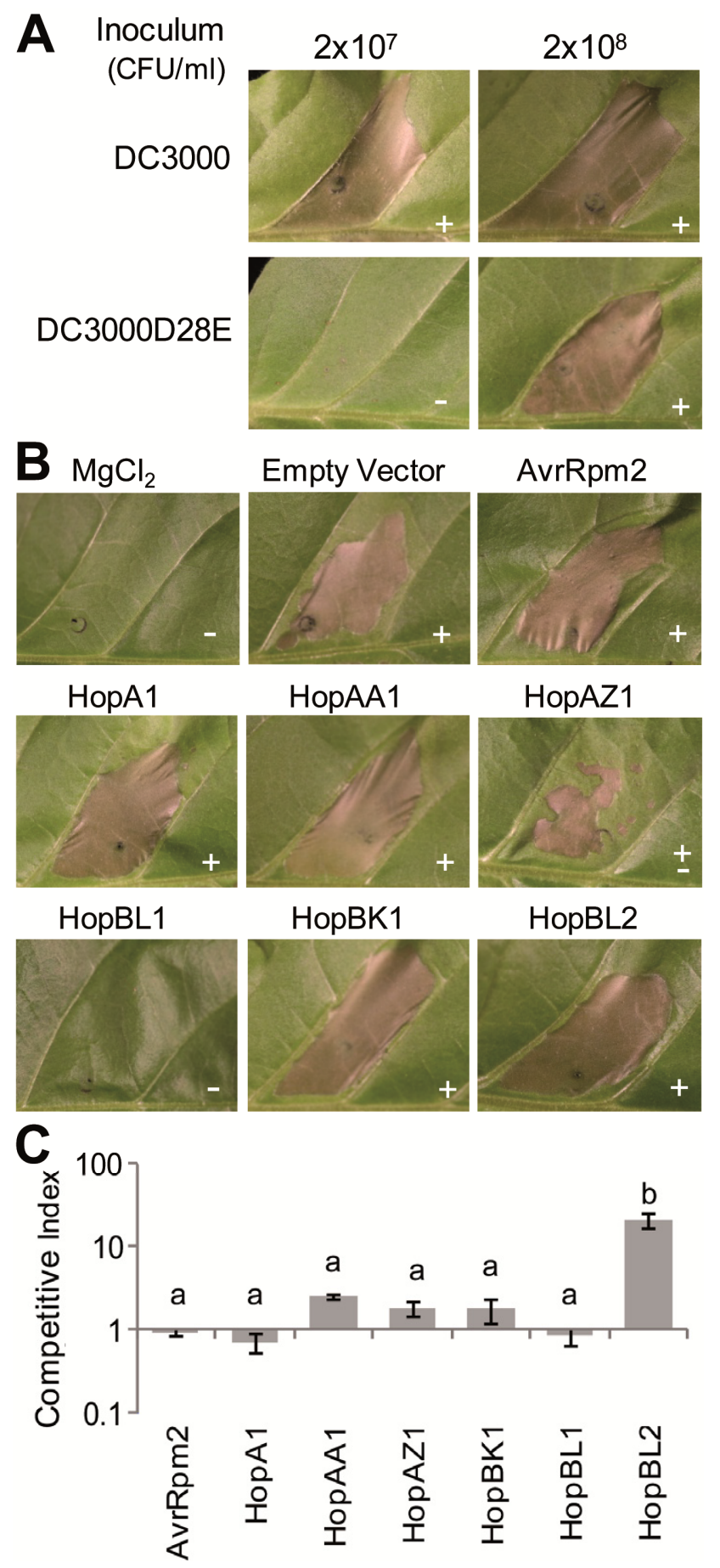


tested. The secretion of HopA1 via the T3SS in $P$. syringae pv. syringae 61 requires the ShcA chaperone (van Dijk et al. 2002). Although a ShcA protein homolog has been annotated in the draft genome of $P$. savastanoi pv. savastanoi (AER0002589), the expression analysis of this effector in this study did not include the NCPPB 3335 ShcA. Thus, we cannot exclude that this protein chaperone may also be necessary for full secretion and in planta activity of HopA1 in P. savastanoi. Conversely, HopA1 from $P$. syringae pv. syringae 61 has been demonstrated to elicit an HR in tobacco when expressed in $P$. fluorescens (Alfano and Collmer 1996). In agreement with these authors, HopA1 expression in DC3000D28E did not suppress the HR response incited by DC3000D28E in tobacco.

DC3000D28E has been demonstrated to be suitable for testing the ability of T3E to restore bacterial growth and induce plant responses (Cunnac et al. 2011). Although the expression of $P$. savastanoi pv. savastanoi HopBL2 in DC3000D28E did not inhibit the ETI-like response induced at high cell doses by DC3000D28E in N. tabacum, HopBL2 expression in this strain significantly increased its competitiveness in $N$. benthamiana (Fig. 6C). Significant DC3000D28E growth restoration in $N$. benthamiana due to the expression of single DC3000 effectors was demonstrated for only AvrPto and AvrPtoB; however, neither other effectors such as HopM1 nor a set of several conserved effectors displayed this effect. Conversely, single DC3000 effectors promoted growth when combined with other effectors in DC3000D28E (Cunnac et al. 2011). Thus, our results suggest that the $P$. savastanoi pv. savastanoi HopBL2, which harbors a C-terminal XopD-like SUMO protease domain (Kim et al. 2011), and HopBL1 might be involved in the inhibition of the initial perception of pathogens. More specifically, XopD has been recently demonstrated to suppress the ethylene production required for anti-Xanthomonas euvesicatoria immunity (Kim et al. 2013). Although the current knowledge of specific T3E functions is limited, our results suggest that the seven $P$. savastanoi T3E analyzed here inhibited PTI, whereas HopAZ1 and HopBL1 also inhibited the ETI-like response. Moreover, and although truncated T3E are generally considered as functionless pseudogenes, our results also demonstrate that the $\mathrm{N}$-terminal region of the truncated versions of HopAA1 and HopAZ1 encoded by P. savastanoi pv. savastanoi NCPPB 3335 (Fig. 4; Supplementary Table S5) are able to interfere with responses associated with plant defense (Figs. 5 and 6). Although no function has been yet established for the HopAZ and HopAA T3E families, P. syringae pv. avellanae HopAZ1 is a promising candidate for modulating hazelnut host specificity (O'Brien et al. 2012). On the other hand, deletion of hopAAl-1 in P. syringae pv. tomato significantly reduced the formation of necrotic speck lesions in tomato leaves (Munkvold et al. 2009). Moreover, HopAA1 has been demonstrated to attenuate the innate immunity in Arabidopsis (Li et al. 2005).

In summary, bioinformatics prediction of proteins belonging to the Ulp1 protease family revealed two novel T3E (HopBL1 and HopBL2) encoded in the genome of $P$. savastanoi pv. savastanoi NCPPB 3335, yielding a final set of 33 T3E candidates in this strain. We demonstrated here that seven of these proteins, including HopBK1, HopBL1, and HopBL2, were translocated into the plant cell via the NCPPB 3335 T3SS and interfered with early responses associated with plant defense. In addition, we demonstrated that HopAZ1 and HopBL1 also inhibited the ETI-like response. Collectively, our results revealed the existence of two novel effector families of the $P$. syringae complex, of which HopBL1 and HopBL2 appear to be specific for $P$. syringae and $P$. savastanoi strains isolated from woody hosts. Future studies should focus on elucidating the precise mechanisms and targets of these and other effectors that are included in the $P$. syringae pangenome and that specifically participate in the infection of woody plants.

\section{MATERIALS AND METHODS}

\section{Bioinformatics analysis.}

Bioinformatics-based predictions of novel candidate T3E in the genome of $P$. savastanoi pv. savastanoi NCPPB 3335 (ASAP Database) were performed by searching for specific protein families corresponding to known T3E that have been previously demonstrated in either $P$. syringae, Xanthomonas spp., or Ralstonia spp. Positive hits were further analyzed for the presence of $\mathrm{N}$-terminal sequence features and potential HrpL boxes in the promoter sequences (500 nucleotides upstream of the start codon), as previously described (RodríguezPalenzuela et al. 2010). Novel candidate T3E meeting both criteria were selected for further investigation.

Sequence alignment using Muscle, determination of the optimal amino acid substitution model, and phylogenetic tree construction were performed using MEGA5 (Tamura et al. 2011). Neighbor-joining and maximum-likelihood phylogenetic trees of the individual protein sequences were generated using MEGA5 with the optimal model (John-Taylor-Thornton model) and the option of complete deletion to eliminate positions containing gaps. Confidence levels for the branching points were determined using 10,000 bootstrap replicates.

\section{Bacterial strains, plasmids, and growth conditions.}

Pseudomonas and Escherichia coli strains were grown at 28 and $37^{\circ} \mathrm{C}$, respectively, using Luria-Bertani (LB) medium (Miller 1972), KB medium (King et al. 1954), or super optimal broth medium (Hanahan 1983). Solid and liquid media were supplemented, when required, with the following antibiotics for the Pseudomonas or E. coli strains: ampicillin (Ap) at 300/100, gentamicin $(\mathrm{Gm})$ at 10/10, spectinomycin (Sp) at $7 / 50$, and kanamycin $(\mathrm{Km})$ at $10 / 50 \mu \mathrm{g} / \mathrm{ml}$. Expression plasmids were generated using Gateway cloning technology (Invitrogen Corp., Carlsbad, CA, U.S.A). Using this system, an open reading frame without a stop codon cloned in an entry vector can be transferred by recombination into a destination vector, creating an in-frame fusion. Entry vectors were constructed by cloning PCR products, amplified with specific primer pairs (Supplementary Table S6), into the plasmid $\mathrm{pENTR/SD/D-TOPO} \mathrm{(Invitrogen} \mathrm{Corp.).} \mathrm{DNA} \mathrm{sequenc-}$ ing using the universal primers T7 and M13-20 confirmed the absence of mutations in the cloned DNA fragments. Expression clones were constructed by combining the pENTR plasmids with the desired expression vector and the LR clonase. The recombination reactions were performed as suggested by the manufacturer (Invitrogen Corp.). Two Gatewaycompatible expression vectors were used: i) pCPP3234, a derivative of the broad host-range vector pVLT35 that employs a tac promoter to express insert genes and generates hybrid proteins with a C-terminal Cya fusion for T3SS translocation studies (Schechter et al. 2004); and ii) pCPP5040, a derivative of the broad-host-range vector pML123 (Labes et al. 1990), which expresses inserted genes from the nptII promoter and generates protein products with a C-terminal HA tag for expression in Pseudomonas spp.

A P. savastanoi pv. savastanoi NCPPB 3335 hprL mutant was constructed using the pIAC4-Km plasmid. First, DNA fragments of approximately $1.2 \mathrm{~kb}$, corresponding to the $5^{\prime}$ and $3^{\prime}$ flanking regions of the NCPPB $3335 \mathrm{hrpL}$ gene, were amplified using three rounds of PCR with NCPPB 3335 genomic DNA as a template and primers that included an EcoRI site and the T7 primer sequence, as previously described 
(Zumaquero et al. 2010). The resulting product was A/T cloned into pGEM-T and fully sequenced to discard mutations on flanking genes. Following sequencing, the resulting plasmid (pIAC4) was tagged with the nptII Km-resistance gene obtained from pGEM-T-KmFRT-EcoRI, yielding pIAC4-Km. For marker-exchange mutagenesis, the pIAC4-Km plasmid was electroporated into NCPPB 3335, as described previously (Pérez-Martínez et al. 2007). Transformants were selected on LB medium containing $\mathrm{Km}$, and the resulting colonies were replica plated onto LB-Ap plates to assess whether each transconjugant integrated the plasmid into the chromosome $\left(A p^{R}\right)$ or engaged in allelic exchange $\left(\mathrm{Ap}^{\mathrm{S}}\right)$. Southern blot analyses, using both $n p t I I$ and $h r p L$ as probes, were used to confirm that allelic exchange occurred at a single position and at the correct site within the genome.

\section{Translocation assay}

of $P$. savastanoi pv. savastanoi NCPPB 3335 T3E candidates.

Translocation assays were performed as previously described by Schechter and collaborators (2004). This method is based on the construction of fusion proteins between identified T3E and the calmodulin-dependent Cya reporter domain. Electrocompetent $P$. savastanoi pv. savastanoi NCPPB 3335 and NCPPB 3335-T3 cells were transformed with Cya fusions, as previously described (Choi et al. 2006). $\mathrm{Sp}^{\mathrm{R}}$ transformants were tested by PCR using a forward primer designed specifically for each T3E gene and a reverse primer annealing to the cya gene (primer Cya-R135). Cya assays were performed in $N$. tabacum var. Newdel plants, as previously described (Schechter et al. 2004). P. savastanoi pv. savastanoi NCPPB 3335 and NCPPB 3335-T3 transformants carrying plasmids expressing T3E-Cya fusions were scraped off of the LB plates, washed twice, and resuspended to an optical density at $600 \mathrm{~nm}$ $\left(\mathrm{OD}_{600}\right)$ of 0.5 (approximately $10^{8} \mathrm{CFU} / \mathrm{ml}$ ) in $5 \mathrm{mM}$ morpholinoethanesulfonic acid ( $\mathrm{pH}$ 5.5) and $100 \mu \mathrm{M}$ isopropyl-thiogalactopyranoside (IPTG). Cell suspensions were injected into the fully expanded upper plant leaves using a 1-ml syringe. Leaf disks were collected at $6 \mathrm{~h}$ postinoculation with a $10-\mathrm{mm}$ inner-diameter cork borer, frozen in liquid nitrogen, ground to a powder, and suspended in $250 \mu \mathrm{l}$ of $0.1 \mathrm{M} \mathrm{HCl}$. The samples were incubated at $-20^{\circ} \mathrm{C}$ overnight, and cAMP levels were determined using a 1:100 dilution of the samples and the Correlate-EIA cAMP immunoassay kit according to the manufacturer's directions (Assay Designs, Inc., Ann Arbor, MI, U.S.A.). The protein content of each sample was determined using the Pierce BCA protein-assay kit (Thermo Scientific, Rockford, IL, U.S.A.).

The Cya activity of the Cya fusion proteins expressed in $E$. coli XL1Blue from pCPP3234 derivatives were assayed as previously reported (Schechter et al. 2004). Bacterial cells were grown in $5 \mathrm{ml}$ of LB medium containing $100 \mu \mathrm{M}$ IPTG to an $\mathrm{OD}_{600}$ of 0.6 to 0.8 . The culture was centrifuged, and the pellet was washed and resuspended in sonication buffer $(20 \mathrm{mM}$ Tris- $\mathrm{HCl}[\mathrm{pH} 8.0]$ and $10 \mathrm{mM} \mathrm{MgCl} 2$ ). The bacteria were sonicated with a microtip for $2 \mathrm{~min}$, and the cellular debris was pelleted by centrifugation. Cya activity was determined in the presence or absence of bovine calmodulin (Calbiochem, Darmstadt, Germany) by using $5 \mu \mathrm{l}$ of each lysate (Sory and Cornelis 1994). cAMP was quantified in bacteria as described above for the leaf samples. Every Cya hybrid protein exhibited calmodulin-dependent Cya activity in E. coli XL1Blue lysates, indicating that all of them could induce cAMP accumulation in planta. The in vitro activity of all the Cya fusions without significant differences in cAMP production in planta between the wild-type $P$. savastanoi pv. savastanoi NCPPB 3335 and its T3SS mutant (strain NCPPB 3335-T3) is illustrated in Supplementary Figure S1.

\section{Plant bioassays.}

The $N$. benthamiana and $N$. tabacum (var. Newdel and var. Xanthi) plants used in this study were 5 to 7 and 4 to 6 weeks old, respectively. The plants were grown with a photoperiod of $16 \mathrm{~h}$ of light and $8 \mathrm{~h}$ of darkness with day and night temperatures of 26 and $22^{\circ} \mathrm{C}$, respectively. Bacterial suspensions in 10 $\mathrm{mM} \mathrm{MgCl}{ }_{2}$ were inoculated into plant leaves using a blunt syringe. Assays with derivatives of $P$. fluorescens 55 (pLN18) were performed by injecting a bacterial suspension $\left(5 \times 10^{7}\right.$ $\mathrm{CFU} / \mathrm{ml}$ ) into $N$. tabacum var. Xanthi leaves using a blunt syringe. The injected areas were lightly marked on the back of the leaves. The bacterial inoculum levels differed among experiments. The bacterial levels in planta were determined by cutting three leaf disks with a boring tool (inner diameter of 10 $\mathrm{mm}$ ) and placing the plant material in $1 \mathrm{ml}$ of $10 \mathrm{mM} \mathrm{MgCl}$. The disks were completely homogenized and the resulting suspensions, containing the bacteria, were diluted and plated on LB-Sp plates (DC3000D28E) or LB-Sp-Gm plates (transformants containing pCPP5040 derivatives). N. tabacum var. Newdel plants were used for the HR assays. The leaves were infiltrated with bacterial suspensions $\left(10^{7}\right.$ and $\left.10^{8} \mathrm{CFU} / \mathrm{ml}\right)$ of $P$. syringae pv. tomato DC3000D28E or its derivatives harboring plasmids expressing each of the different $P$. savastanoi $\mathrm{pv}$. savastanoi T3E. The generated symptoms, scored $48 \mathrm{~h}$ after inoculation, were captured with a high-resolution digital camera (Nikon DXM 1200; Nikon Corporation, Tokyo).

For competition assays, the $N$. benthamiana leaves were inoculated with mixed suspensions containing equal $\mathrm{CFU}$ (approximately $10^{4} \mathrm{CFU} / \mathrm{ml}$ ) of $P$. syringae pv. tomato DC3000D28E and each of its transformants carrying pCPP5040 derivatives expressing $P$. savastanoi pv. savastanoi T3E. Input and ouput pools assayed 1 and $6 \mathrm{~h}$ after inoculation, respectively, were plated onto LB-Sp and LB-Sp-Gm to select for DC3000D28E and the transformants with pCPP5040 derivatives, respectively. A CI was calculated by dividing the output ratio (CFU transformant:CFU DC3000D28E) by the input ratio (CFU transformant:CFU DC3000D28E). CI of the transformant strains expressing $P$. savastanoi pv. savastanoi T3E versus DC3000D28E were normalized with respect to the CI obtained for DC3000D28E (pCPP5040). The CI presented in Figure 6 represent the mean of three replicates demonstrating typical results from three independent experiments. The results were statistically analyzed using one-way analysis of variance (ANOVA) followed by post-hoc comparisons using the Tukey test. Statistical analysis of the results obtained for CI revealed significant differences $(F[7 / 41]=17,273, P \leq$ 0.0001 ).

Olive plants derived from seed germinated in vitro (originally collected from an 'Arbequina' plant) were micropropagated, rooted, and maintained as previously described (Rodríguez-Moreno et al. 2008, 2009). To analyze the pathogenicity of the $P$. savastanoi pv. savastanoi NCPPB 3335 $\Delta h r p L$ mutant in 1-year-old olive explants (woody plants), micropropagated olive plants were transferred into soil and maintained in a glasshouse at $27^{\circ} \mathrm{C}$ with a relative humidity of $58 \%$ under natural daylight. The plant stems were wounded and infected with approximately $10^{6} \mathrm{CFU}$ of $P$. savastanoi $\mathrm{pv}$. savastanoi as previously described (Penyalver et al. 2006; Pérez-Martínez et al. 2007). Morphological changes, scored at 90 days postinoculation, were captured with a high-resolution digital camera (Nikon DXM 1200).

\section{Detection of ROS production and callose deposition.}

ROS production was observed after DAB staining (ThordalChristensen et al. 1997) $4 \mathrm{~h}$ after inoculation with $P$. fluorescens 55 (pLN18) derivatives. Bacterial suspensions $\left(10^{8} \mathrm{CFU} / \mathrm{ml}\right)$ were inoculated into $N$. tabacum var. Xanthi leaves using a blunt 
syringe. Small pieces of tobacco leaves cut from around the injection area were placed into a syringe and stained by vacuum infiltration of a freshly prepared $1 \mathrm{mg} / \mathrm{ml}$ solution of DAB (Sigma-Aldrich D-8001; Sigma-Aldrich, Inc., St. Louis) in $8 \mathrm{mM} \mathrm{HCl}$, pH 3.8. Chlorophyll was removed by submerging the leaves into a solution of ethanol/lactic acid/glycerol $(3: 1: 1[\mathrm{vol} / \mathrm{vol} / \mathrm{vol}])$ at $60^{\circ} \mathrm{C}$ and stored overnight at room temperature on water-soaked filter paper. At least 10 biological replicates from each specimen were mounted on slides in a $50 \%$ glycerol (vol/vol) solution and observed with a Nikon Eclipse E800 microscope (Nikon Corporation) under bright field. DAB staining produces an intensely brown precipitate at the sites of ROS production, which were next to the infection zone.

Callose deposition samples were developed $12 \mathrm{~h}$ after inoculation and stained as described previously (Guo et al. 2009). Chlorophyll was removed in $95 \%$ (vol/vol) ethanol from small pieces of tobacco leaves, which were cut from around the injection area, and staining was performed in a $0.02 \%$ (wt/vol) solution of aniline blue (number 415049; Sigma-Aldrich, Inc.) in $150 \mathrm{mM}$ potassium phosphate, $\mathrm{pH} \mathrm{9,} \mathrm{for} 1 \mathrm{~h}$ in the dark. At least 10 biological replicates from each specimen were mounted in $50 \%$ (vol/vol) glycerol on glass slides. Observations were conducted under UV-light excitation using the filter UV-2 ${ }^{\mathrm{a}}$ (EX 330-380, DM 400; BA 420) on a Nikon Eclipse E 800 microscope (Nikon Corporation).

ROS production and callose deposition were quantified as previously described (Rodríguez-Herva et al. 2012), with slight modifications. Up to four snapshots of each specimen from equivalent areas surrounding the wound (inoculation zone) were captured with a Nikon DXM1200 camera using the Nikon ACT-1 2.70 software. The same settings and a final magnification of $\times 40$ were applied to all the samples. After calibrating all the images using the scale bar included in each picture, DAB staining and aniline blue fluorescence were quantified using the program Visilog 6.3 (Noesis, Les Ulis, France). For this purpose, the characteristic brown color of the DAB precipitate and the specific blue fluorescence of callose deposition (Fig. 5) were separated by color deconvolution using the i_classification command. Then, the stained areas were quantified and the results were expressed in square millimeters. Five to six images per assay were analyzed, and statistical analyses were performed using one-way ANOVA followed by post-hoc comparisons using the Tukey test. Statistical analysis of the results obtained for ROS production and callose deposition revealed significant differences $(F[8 / 44]=59.12, P \leq 0.0001$ and $F[8 / 44]=24.33, P \leq 0.0001$, respectively).

\section{Colony blots.}

To fix total DNA from the colonies, overnight cultures of Pseudomonas strains grown on LB microtiter plates were transferred onto nylon membranes placed on LB agar plates using a 48-pin replicator (Sigma-Aldrich, Inc.). Total DNA from the bacterial colonies was denatured on the membranes by alkaline lysis by placing a Whatman $3 \mathrm{MM}$ paper soaked in denaturing solution $(0.4 \mathrm{M} \mathrm{NaOH})$ for $15 \mathrm{~min}$ on top of the colonies. The membranes were neutralized twice for $15 \min$ in $1 \mathrm{M} \mathrm{NaCl}$ and $0.5 \mathrm{M}$ Tris, $\mathrm{pH} 7.2$, then washed twice for $10 \mathrm{~min}$ in $2 \times$ $\mathrm{SSC}(1 \times \mathrm{SSC}$ is $0.15 \mathrm{M} \mathrm{NaCl}$ plus $0.015 \mathrm{M}$ sodium citrate). Finally, the DNA was cross-linked by UV fixation (Vilber Lourmat, Eberhardzell, Germany). DNA probes were amplified and labeled by PCR using primers and digoxigenin (DIG)dNTPs from the Dig labeling mix kit (Roche Applied Science, Mannheim, Germany), and the appropriate pENTRY plasmid as the DNA template. Hybridization was performed at $65^{\circ} \mathrm{C}$ using the DIG Nucleic Acid Detection Kit (Roche Applied Science), following the manufacturer's instructions.
qRT-PCR assays.

Pure cultures of the wild-type $P$. savastanoi pv. savastanoi NCPPB 3335 and its $\Delta h r p L$ mutant were grown overnight in $\mathrm{KB}$ medium at $28^{\circ} \mathrm{C}$. The cells were diluted in fresh $\mathrm{KB}$ medium and incubated with shaking at $28^{\circ} \mathrm{C}$ to an $\mathrm{OD}_{600}$ of 0.5 . The sample was split into two. One half was pelleted and frozen (for noninducing condition) and the other half was pelleted, washed twice with $10 \mathrm{mM} \mathrm{MgCl}_{2}$, and resuspended in the same volume of Hrp-inducing medium (Huynh et al. 1989) supplemented with $5 \mathrm{mM}$ mannitol and $0.0006 \%$ ferric citrate (Roine et al. 1997; Sambrook and Russell 2001). After $6 \mathrm{~h}$ of incubation, the cells were pelleted and processed for RNA isolation using TriPure Isolation Reagent (Roche Applied Science) according to the manufacturer's instructions, except that the TriPure was preheated at $65^{\circ} \mathrm{C}$, the lysis step was performed at $65^{\circ} \mathrm{C}$, and BCP (Molecular Research Center, Cincinnati, $\mathrm{OH}$, U.S.A.) was used instead of chloroform. Total RNA was treated with the RNAeasy kit (Qiagen GmbH, Hilden, Germany), as detailed by the manufacturer. The RNA concentration was determined spectrophotometrically and its integrity was assessed by agarose gel electrophoresis. DNA-free total RNA was retrotranscribed to cDNA using the cDNA Reverse Transcription kit (Applied Biosystems, Foster City, CA, U.S.A.) and random hexamers. The primer efficiency tests, qRT-PCRs, and confirmation of the specificity of the amplification reactions were performed as described previously (Vargas et al. 2011). The relative transcript abundance was calculated using the $\Delta \Delta$ cyclethreshold (Ct) method (Livak and Schmittgen 2001). Transcriptional data were normalized to the housekeeping gene gyrA using the Roche LightCycler 480 Software and are presented as the fold change in expression compared with the expression of each gene in the wild-type strain. The relative expression ratio was calculated as the difference in qPCR threshold cycles $(\Delta \mathrm{Ct}=\mathrm{Ctgene}$ of interest $-\mathrm{CtgyrA})$. One PCR cycle represents a twofold difference in template abundance; therefore, fold-change values were calculated as $2^{-\Delta \Delta \mathrm{Ct}}$, as previously described (Pfaffl 2001; Rotenberg et al. 2006). qRT-PCRs were performed in triplicate.

\section{ACKNOWLEDGMENTS}

This study was supported by Spanish Plan Nacional I+D+i grants AGL2011-30343-C02-01, AGL2011-30343-C02-02, and AGL2012-32516 from the Ministerio de Economía y Competitividad (MINECO), cofinanced by FEDER, and by the grant P08-CVI-03475 from the Junta de Andalucía, Spain. I. M. Matas, I. M. Aragón, and M. P. Castañeda-Ojeda were supported by the Ramón Areces Foundation (Spain) and by FPU and FPI fellowships from the MINECO, respectively. We thank M. Vega Sánchez for excellent assistance with image analysis for quantifying ROS production and callose deposition, L. Santín (University of Malaga, Spain) for statistical analysis of data, and A. Barceló and I. Imbroda (IFAPA, Churriana, Spain) for micropropagating the olive plants.

\section{LITERATURE CITED}

Alfano, J. R., and Collmer, A. 1996. Bacterial pathogens in plants: Life up against the wall. Plant Cell 8:1683-1698.

Badel, J. L., Nomura, K., Bandyopadhyay, S., Shimizu, R., Collmer, A., and He, S. Y. 2003. Pseudomonas syringae pv. tomato DC3000 HopPtoM (CEL ORF3) is important for lesion formation but not growth in tomato and is secreted and translocated by the Hrp type III secretion system in a chaperone-dependent manner. Mol. Microbiol. 49:12391251.

Badel, J. L., Shimizu, R., Oh, H. S., and Collmer, A. 2006. A Pseudomonas syringae pv. tomato avrE1/hopM1 mutant is severely reduced in growth and lesion formation in tomato. Mol. Plant-Microbe Interact. 19:99-111.

Baltrus, D. A., Nishimura, M. T., Romanchuk, A., Chang, J. H., Mukhtar, M. S., Cherkis, K., Roach, J., Grant, S. R., Jones, C. D., and Dangl, J. L. 2011. Dynamic evolution of pathogenicity revealed by sequencing and comparative genomics of 19 Pseudomonas syringae isolates. PLoS 
Pathog. 7:e1002132. Published online.

Baltrus, D. A., Nishimura, M. T., Dougherty, K. M., Biswas, S., Mukhtar, M. S., Vicente, J., Holub, E. B., and Dangl, J. L. 2012. The molecular basis of host specialization in bean pathovars of Pseudomonas syringae. Mol. Plant-Microbe Interact. 25:877-888.

Bardaji, L., Pérez-Martínez, I., Rodríguez-Moreno, L., RodríguezPalenzuela, P., Sundin, G. W., Ramos, C., and Murillo, J. 2011. Sequence and role in virulence of the three plasmid complement of the model tumor-inducing bacterium Pseudomonas savastanoi pv. savastanoi NCPPB 3335. PLoS One 6:e25705. Published online.

Block, A., and Alfano, J. R. 2011. Plant targets for Pseudomonas syringae type III effectors: Virulence targets or guarded decoys? Curr. Opin. Microbiol. 14:39-46.

Boller, T., and Felix, G. 2009. A renaissance of elicitors: Perception of microbe-associated molecular patterns and danger signals by patternrecognition receptors. Annu. Rev. Plant Biol. 60:379-406.

Bradley, D. J., Kjellbom, P., and Lamb, C. J. 1992. Elicitor- and woundinduced oxidative cross-linking of a proline-rich plant cell wall protein: A novel, rapid defense response. Cell 70:21-30.

Casper-Lindley, C., Dahlbeck, D., Clark, E. T., and Staskawicz, B. J. 2002. Direct biochemical evidence for type III secretion-dependent translocation of the AvrBs2 effector protein into plant cells. Proc. Natl. Acad. Sci. U.S.A. 99:8336-8341.

Chang, J. H., Urbach, J. M., Law, T. F., Arnold, L. W., Hu, A., Gombar, S., Grant, S. R., Ausubel, F. M., and Dangl, J. L. 2005. A high-throughput, near-saturating screen for type III effector genes from Pseudomonas syringae. Proc. Natl. Acad. Sci. U.S.A. 102:2549-2554.

Chisholm, S. T., Coaker, G., Day, B., and Staskawicz, B. J. 2006. Hostmicrobe interactions: Shaping the evolution of the plant immune response. Cell 124:803-814.

Choi, K. H., Kumar, A., and Schweizer, H. P. 2006. A 10-min method for preparation of highly electrocompetent Pseudomonas aeruginosa cells Application for DNA fragment transfer between chromosomes and plasmid transformation. J. Microbiol. Methods 64:391-397.

Collmer, A., Schneider, D. J., and Lindeberg, M. 2009. Lifestyles of the effector rich: Genome-enabled characterization of bacterial plant pathogens. Plant Physiol. 150:1623-1630.

Conrath, U. 2011. Molecular aspects of defence priming. Trends Plant Sci. 16:524-531

Cunnac, S., Lindeberg, M., and Collmer, A. 2009. Pseudomonas syringae type III secretion system effectors: Repertoires in search of functions. Curr. Opin. Microbiol. 12:53-60.

Cunnac, S., Chakravarthy, S., Kvitko, B. H., Russell, A. B., Martin, G. B., and Collmer, A. 2011. Genetic disassembly and combinatorial reassembly identify a minimal functional repertoire of type III effectors in Pseudomonas syringae. Proc. Natl. Acad. Sci. U.S.A. 108:2975-2980.

de Torres, M., Mansfield, J. W., Grabov, N., Brown, I. R., Ammouneh, H., Tsiamis, G., Forsyth, A., Robatzek, S., Grant, M., and Boch, J. 2006. Pseudomonas syringae effector AvrPtoB suppresses basal defence in Arabidopsis. Plant J. 47:368-382.

Doke, N. 1983. Involvement of superoxide anion generation in the hypersensitive response of potato tuber tissues to infection with an incompatible race of Phytophthora infestans and to the hyphal wall components. Physiol. Plant Pathol. 23:345-357.

Fouts, D. E., Abramovitch, R. B., Alfano, J. R., Baldo, A. M., Buell, C. R., Cartinhour, S., Chatterjee, A. K., D'Ascenzo, M., Gwinn, M. L., Lazarowitz, S. G., Lin, N. C., Martin, G. B., Rehm, A. H., Schneider, D. J., van Dijk, K., Tang, X., and Collmer, A. 2002. Genomewide identification of Pseudomonas syringae pv. tomato DC3000 promoters controlled by the HrpL alternative sigma factor. Proc. Natl. Acad. Sci. U.S.A. 99:2275-2280

Guo, M., Tian, F., Wamboldt, Y., and Alfano, J. R. 2009. The majority of the type III effector inventory of Pseudomonas syringae pv. tomato DC3000 can suppress plant immunity. Mol. Plant-Microbe Interact. 22:1069-1080.

Hanahan, D. 1983. Studies on transformation of Escherichia coli with plasmids. J. Mol. Biol. 166:557-580.

Hirano, S. S., and Upper, C. D. 2000. Bacteria in the leaf ecosystem with emphasis on Pseudomonas syringae-a pathogen, ice nucleus, and epiphyte. Microbiol. Mol. Biol. Rev. 64:624-653.

Huckelhoven, R. 2007. Cell wall-associated mechanisms of disease resistance and susceptibility. Annu. Rev. Phytopathol. 45:101-127.

Huynh, T. V., Dahlbeck, D., and Staskawicz, B. J. 1989. Bacterial blight of soybean: Regulation of a pathogen gene determining host cultivar specificity. Science 245:1374-1377.

Jackson, R. W., Athanassopoulos, E., Tsiamis, G., Mansfield, J. W., Sesma, A., Arnold, D. L., Gibbon, M. J., Murillo, J., Taylor, J. D., and Vivian, A. 1999. Identification of a pathogenicity island, which contains genes for virulence and avirulence, on a large native plasmid in the bean pathogen Pseudomonas syringae pathovar phaseolicola. Proc.
Natl. Acad. Sci. U.S.A. 96:10875-10880.

Jamir, Y., Guo, M., Oh, H. S., Petnicki-Ocwieja, T., Chen, S., Tang, X., Dickman, M. B., Collmer, A., and Alfano, J. R. 2004. Identification of Pseudomonas syringae type III effectors that can suppress programmed cell death in plants and yeast. Plant J. 37:554-565.

Janjusevic, R., Abramovitch, R. B., Martin, G. B., and Stebbins, C. E. 2006. A bacterial inhibitor of host programmed cell death defenses is an E3 ubiquitin ligase. Science 311:222-226.

Jones, J. D., and Dangl, J. L. 2006. The plant immune system. Nature 444:323-329.

Katagiri, F., and Tsuda, K. 2010. Understanding the plant immune system. Mol. Plant-Microbe Interact. 23:1531-1536.

Kay, S., and Bonas, U. 2009. How Xanthomonas type III effectors manipulate the host plant. Curr. Opin. Microbiol. 12:37-43.

Kim, J. G., Taylor, K. W., and Mudgett, M. B. 2011. Comparative analysis of the XopD type III secretion (T3S) effector family in plant pathogenic bacteria. Mol. Plant Pathol. 12:715-730.

Kim, J. G., Stork, W., and Mudgett, M. B. 2013. Xanthomonas type III effector XopD desumoylates tomato transcription factor SIERF4 to suppress ethylene responses and promote pathogen growth. Cell Host Microbe 13:143-154.

King, E. O., Ward, M. K., and Raney, D. E. 1954. Two simple media for the demonstration of pyocyanin and fluorescin. J. Lab. Clin. Med. 44:301-307.

Kvitko, B. H., Ramos, A. R., Morello, J. E., Oh, H. S., and Collmer, A. 2007. Identification of harpins in Pseudomonas syringae pv. tomato DC3000, which are functionally similar to HrpK1 in promoting translocation of type III secretion system effectors. J. Bacteriol. 189:80598072

Labes, M., Puhler, A., and Simon, R. 1990. A new family of RSF1010derived expression and lac-fusion broad-host-range vectors for gramnegative bacteria. Gene 89:37-46.

Levine, A., Tenhaken, R., Dixon, R., and Lamb, C. 1994. $\mathrm{H}_{2} \mathrm{O}_{2}$ from the oxidative burst orchestrates the plant hypersensitive disease resistance response. Cell 79:583-593.

Li, C., Potuschak, T., Colon-Carmona, A., Gutierrez, R. A., and Doerner, P. 2005. Arabidopsis TCP20 links regulation of growth and cell division control pathways. Proc. Natl. Acad. Sci. U.S.A. 102:12978-12983.

Lin, N. C., Abramovitch, R. B., Kim, Y. J., and Martin, G. B. 2006. Diverse AvrPtoB homologs from several Pseudomonas syringae pathovars elicit Pto-dependent resistance and have similar virulence activities. Appl. Environ. Microbiol. 72:702-712.

Lindeberg, M. 2012. Genome-enabled perspectives on the composition, evolution, and expression of virulence determinants in bacterial plant pathogens. Annu. Rev. Phytopathol. 50:111-132.

Lindeberg, M., Stavrinides, J., Chang, J. H., Alfano, J. R., Collmer, A., Dangl, J. L., Greenberg, J. T., Mansfield, J. W., and Guttman, D. S. 2005. Proposed guidelines for a unified nomenclature and phylogenetic analysis of type III Hop effector proteins in the plant pathogen Pseudomonas syringae. Mol. Plant-Microbe Interact. 18:275-282.

Lindeberg, M., Myers, C. R., Collmer, A., and Schneider, D. J. 2008. Roadmap to new virulence determinants in Pseudomonas syringae: Insights from comparative genomics and genome organization. Mol. Plant-Microbe Interact. 21:685-700.

Lindeberg, M., Cunnac, S., and Collmer, A. 2012. Pseudomonas syringae type III effector repertoires: Last words in endless arguments. Trends Microbiol. 20:199-208.

Livak, K. J., and Schmittgen, T. D. 2001. Analysis of relative gene expression data using real-time quantitative PCR and the $2-\Delta \Delta C T$ method. Methods 25:402-408.

Lopez-Solanilla, E., Bronstein, P. A., Schneider, A. R., and Collmer, A. 2004. HopPtoN is a Pseudomonas syringae Hrp (type III secretion system) cysteine protease effector that suppresses pathogen-induced necrosis associated with both compatible and incompatible plant interactions. Mol. Microbiol. 54:353-365.

Mansfield, J. W. 2009. From bacterial avirulence genes to effector functions via the hrp delivery system: An overview of 25 years of progress in our understanding of plant innate immunity. Mol. Plant Pathol. 10:721-734.

Matas, I. M., Lambertsen, L., Rodríguez-Moreno, L., and Ramos, C. 2012. Identification of novel virulence genes and metabolic pathways required for full fitness of Pseudomonas savastanoi pv. savastanoi in olive (Olea europaea) knots. New Phytol. 196:1182-1196.

Miller, J. H. 1972. Experiments in Molecular Genetics. Cold Spring Harbor Laboratory, Cold Spring Harbor, NY, U.S.A

Munkvold, K. R., Russell, A. B., Kvitko, B. H., and Collmer, A. 2009. Pseudomonas syringae pv. tomato DC3000 type III effector HopAA1-1 functions redundantly with chlorosis-promoting factor PSPTO4723 to produce bacterial speck lesions in host tomato. Mol. Plant-Microbe Interact. 22:1341-1355. 
Mur, L. A., Kenton, P., Lloyd, A. J., Ougham, H., and Prats, E. 2008. The hypersensitive response; the centenary is upon us but how much do we know? J. Exp. Bot. 59:501-520.

O’Brien, H. E., Thakur, S., Gong, Y., Fung, P., Zhang, J., Yuan, L., Wang, P. W., Yong, C., Scortichini, M., and Guttman, D. S. 2012. Extensive remodeling of the Pseudomonas syringae pv. avellanae type III secretome associated with two independent host shifts onto hazelnut. BMC Microbiol. 12:141.

Oh, H. S., Park, D. H., and Collmer, A. 2010. Components of the Pseudomonas syringae type III secretion system can suppress and may elicit plant innate immunity. Mol. Plant-Microbe Interact. 23:727-739.

Penyalver, R., García, A., Ferrer, A., Bertolini, E., Quesada, J. M. Salcedo, C. I., Piquer, J., Pérez-Panades, J., Carbonell, E. A., Del Rio, C., Caballero, J. M., and López, M. M. 2006. Factors affecting Pseudomonas savastanoi pv. savastanoi plant inoculations and their use for evaluation of Olive cultivar susceptibility. Phytopathology 96:313319

Pérez-Martínez, I., Rodríguez-Moreno, L., Matas, I. M., and Ramos, C. 2007. Strain selection and improvement of gene transfer for genetic manipulation of Pseudomonas savastanoi isolated from olive knots. Res. Microbiol. 158:60-69.

Pérez-Martínez, I., Rodríguez-Moreno, L., Lambertsen, L., Matas, I.M. Murillo, J., Tegli, S., Jiménez, A.J., and Ramos, C. 2010. Fate of a Pseudomonas savastanoi pv. savastanoi type III secretion system mutant in olive plants (Olea europaea L.). Appl. Environ. Microbiol. 76:3611-3619.

Pfaffl, M. W. 2001. A new mathematical model for relative quantification in real-time RT-PCR. Nucleic Acids Res. 29:e45.

Ramos, C., Matas, I. M., Bardaji, L., Aragón, I. M., and Murillo, J. 2012. Pseudomonas savastanoi pv. savastanoi: Some like it knot. Mol. Plant Pathol. 13:998-1009.

Rodríguez-Herva, J. J., González-Melendi, P., Cuartas-Lanza, R., AntúnezLamas, M., Rio-Alvarez, I., Li, Z., López-Torrejon, G., Díaz, I., Del Pozo, J. C., Chakravarthy, S., Collmer, A., Rodríguez-Palenzuela, P., and López-Solanilla, E. 2012. A bacterial cysteine protease effector protein interferes with photosynthesis to suppress plant innate immune responses. Cell Microbiol. 14:669-681.

Rodríguez-Moreno, L., Barceló-Muñoz, A., and Ramos, C. 2008. In vitro analysis of the interaction of Pseudomonas savastanoi pvs. savastanoi and nerii with micropropagated olive plants. Phytopathology 98:815822.

Rodríguez-Moreno, L., Jiménez, A. J., and Ramos, C. 2009. Endopathogenic lifestyle of Pseudomonas savastanoi pv. savastanoi in olive knots. Microb. Biotechnol. 2:476-488.

Rodríguez-Palenzuela, P., Matas, I. M., Murillo, J., López-Solanilla, E., Bardaji, L., Pérez-Martínez, I., Rodríguez-Moskera, M. E., Penyalver, R., López, M. M., Quesada, J. M., Biehl, B. S., Perna, N. T., Glasner, J. D., Cabot, E. L., Neeno-Eckwall, E., and Ramos, C. 2010. Annotation and overview of the Pseudomonas savastanoi pv. savastanoi NCPPB3335 draft genome reveals the virulence gene complement of a tumour-inducing pathogen of woody hosts. Environ. Microbiol. 12:1604-1620.

Roine, E., Saarinen, J., Kalkkinen, N., and Romantschuk, M. 1997. Purified HrpA of Pseudomonas syringae pv. tomato DC3000 reassembles into pili. FEBS (Fed. Eur. Biochem. Soc.) Lett. 417:168-172.

Rotenberg, D., Thompson, T. S., German, T. L., and Willis, D. K. 2006. Methods for effective real-time RT-PCR analysis of virus-induced gene silencing. J. Virol. Methods 138:49-59.

Sambrook, J., and Russell, D. 2001. Molecular Cloning: A Laboratory Manual. Cold Spring Harbor Laboratory Press, Cold Spring Harbor, NY, U.S.A.

Schechter, L. M., Roberts, K. A., Jamir, Y., Alfano, J. R., and Collmer, A. 2004. Pseudomonas syringae type III secretion system targeting signals and novel effectors studied with a Cya translocation reporter. J. Bacteriol. 186:543-555.

Schechter, L. M., Vencato, M., Jordan, K. L., Schneider, S. E., Schneider, D. J., and Collmer, A. 2006. Multiple approaches to a complete inventory of Pseudomonas syringae pv. tomato DC3000 type III secretion system effector proteins. Mol. Plant-Microbe Interact. 19:1180-1192.

Sory, M. P., and Cornelis, G. R. 1994. Translocation of a hybrid YopEadenylate cyclase from Yersinia enterocolitica into HeLa cells. Mol. Microbiol. 14:583-594.

Tamura, K., Peterson, D., Peterson, N., Stecher, G., Nei, M., and Kumar, S. 2011. MEGA5: Molecular evolutionary genetics analysis using maximum likelihood, evolutionary distance, and maximum parsimony methods. Mol. Biol. Evol. 28:2731-2739.

Thordal-Christensen, H., Zhang, Z., Wei, Y., and Collinge, D. B. 1997. Subcellular localization of $\mathrm{H}_{2} \mathrm{O}_{2}$ in plants, $\mathrm{H}_{2} \mathrm{O}_{2}$ accumulation in papillae and hypersensitive response during barley-powdery mildew interaction. Plant J. 11:1187-1194.

Torres, M. A., and Dangl, J. L. 2005. Functions of the respiratory burst oxidase in biotic interactions, abiotic stress and development. Curr. Opin. Plant Biol. 8:397-403.

Underwood, W., Zhang, S., and He, S.Y. 2007. The Pseudomonas syringae type III effector tyrosine phosphatase HopAO1 suppresses innate immunity in Arabidopsis thaliana. Plant J. 52:658-672.

van Dijk, K., Tam, V. C., Records, A. R., Petnicki-Ocwieja, T., and Alfano, J. R. 2002. The ShcA protein is a molecular chaperone that assists in the secretion of the HopPsyA effector from the type III (Hrp) protein secretion system of Pseudomonas syringae. Mol. Microbiol. 44:14691481

Vargas, P., Felipe, A., Michan, C., and Gallegos, M. T. 2011. Induction of Pseudomonas syringae pv. tomato DC3000 MexAB-OprM multidrug efflux pump by flavonoids is mediated by the repressor PmeR. Mol. Plant-Microbe Interact. 24:1207-1219.

Vencato, M., Tian, F., Alfano, J. R., Buell, C. R., Cartinhour, S., DeClerck, G. A., Guttman, D. S., Stavrinides, J., Joardar, V., Lindeberg, M., Bronstein, P. A., Mansfield, J. W., Myers, C. R., Collmer, A., and Schneider, D. J. 2006. Bioinformatics-enabled identification of the HrpL regulon and type III secretion system effector proteins of Pseudomonas syringae pv. phaseolicola 1448A. Mol. Plant-Microbe Interact. 19:1193-1206.

Vinatzer, B. A., Teitzel, G. M., Lee, M. W., Jelenska, J., Hotton, S., Fairfax, K., Jenrette, J., and Greenberg, J. T. 2006. The type III effector repertoire of Pseudomonas syringae pv. syringae B728a and its role in survival and disease on host and non-host plants. Mol. Microbiol. 62:2644.

Xiao, Y., and Hutcheson, S. W. 1994. A single promoter sequence recognized by a newly identified alternate sigma factor directs expression of pathogenicity and host range determinants in Pseudomonas syringae. J. Bacteriol. 176:3089-3091.

Young, J. M. 2010. Taxonomy of Pseudomonas syringae. J. Plant Pathol. 92:S1.5-S1.14

Zumaquero, A., Macho, A. P., Rufian, J. S., and Beuzón, C. R. 2010. Analysis of the role of the type III effector inventory of Pseudomonas syringae pv. phaseolicola 1448a in interaction with the plant. J. Bacteriol. 192:4474-4488.

\section{AUTHOR-RECOMMENDED INTERNET RESOURCES}

ASAP database: www.genome.wisc.edu/tools/asap.htm Junta de Andalucía website: www.juntadeandalucia.es Pfam database: pfam.sanger.ac.uk

Pseudomonas syringae genome resources home page: www.pseudomonas-syringae.org 